\title{
Potential bioavailability of organic matter from atmospheric particles to marine heterotrophic bacteria
}

\author{
Kahina Djaoudi ${ }^{1,2}$, France Van Wambeke ${ }^{1}$, Aude Barani ${ }^{1}$, Nagib Bhairy ${ }^{1}$, Servanne Chevaillier $^{5}$, Karine Desboeufs ${ }^{5}$, \\ Sandra Nunige ${ }^{1}$, Mohamed Labiadh ${ }^{3}$, Thierry Henry des Tureaux ${ }^{4}$, Dominique Lefèvre ${ }^{1}$, Amel Nouara $^{1}$, \\ Christos Panagiotopoulos ${ }^{1}$, Marc Tedetti ${ }^{1}$, and Elvira Pulido-Villena ${ }^{1}$ \\ ${ }^{1}$ Aix-Marseille Univ., Université de Toulon, CNRS, IRD, MIO UM 110, 13288, Marseille, France \\ ${ }^{2}$ Molecular and Cellular Biology, The University of Arizona, Tucson, USA \\ ${ }^{3}$ IRA (Institut des Régions Arides) de Médenine, El Fjé4119, Médenine, Tunisia \\ ${ }_{4}^{4}$ EES Paris (Institut d'Ecologie et des Sciences de l'Environnement de Paris), UMR IRD 242, Université Paris Est \\ Créteil-Sorbonne Université-CNRS-INRA-Université de Paris, 93143 Bondy, France \\ ${ }^{5}$ LISA, UMR7583, Université de Paris, Université Paris-Est-Créteil, Institut Pierre Simon Laplace (IPSL), Créteil, France
}

Correspondence: Kahina Djaoudi (kdjaoudi@email.arizona.edu)

Received: 24 May 2020 - Discussion started: 23 July 2020

Revised: 29 October 2020 - Accepted: 18 November 2020 - Published: 14 December 2020

\begin{abstract}
The surface ocean receives important amounts of organic carbon from atmospheric deposition. The degree of bioavailability of this source of organic carbon will determine its impact on the marine carbon cycle. In this study, the potential availability of dissolved organic carbon (DOC) leached from both desert dust and anthropogenic aerosols to marine heterotrophic bacteria was investigated. The experimental design was based on $16 \mathrm{~d}$ incubations, in the dark, of a marine bacterial inoculum into artificial seawater amended with water-soluble Saharan dust (D treatment) and anthropogenic (A treatment) aerosols, so that the initial DOC concentration was similar between treatments. Glucose-amended (G) and non-amended (control) treatments were run in parallel. Over the incubation period, an increase in bacterial abundance (BA) and bacterial production (BP) was observed first in the $G$ treatment, followed then by the $\mathrm{D}$ and finally A treatments, with bacterial growth rates significantly higher in the $G$ and $D$ treatments than the A treatment. Following this growth, maxima of BP reached were similar in the $\mathrm{D}\left(879 \pm 64 \mathrm{ng} \mathrm{CL}^{-1} \mathrm{~h}^{-1} ; n=3\right)$ and $\mathrm{G}\left(648 \pm 156 \mathrm{ng} \mathrm{C} \mathrm{L}^{-1} \mathrm{~h}^{-1} ; n=3\right)$ treatments and were significantly higher than in the A treatment $\left(124 \mathrm{ng} \mathrm{CL}^{-1} \mathrm{~h}^{-1}\right.$; $n=2$ ). The DOC consumed over the incubation period was similar in the $\mathrm{A}(9 \mu \mathrm{M} ; n=2)$ and $\mathrm{D}(9 \pm 2 \mu \mathrm{M} ; n=3)$ treatments and was significantly lower than in the $G$ treatment $(22 \pm 3 \mu \mathrm{M} ; n=3)$. Nevertheless, the bacterial growth effi-
\end{abstract}

ciency (BGE) in the D treatment $(14.2 \pm 5.5 \% ; n=3)$ compared well with the $\mathrm{G}$ treatment $(7.6 \pm 2 \% ; n=3)$, suggesting that the metabolic use of the labile DOC fraction in both conditions was energetically equivalent. In contrast, the BGE in the A treatment was lower $(1.7 \% ; n=2)$, suggesting that most of the used labile DOC was catabolized. The results obtained in this study highlight the potential of aerosol organic matter to sustain the metabolism of marine heterotrophs and stress the need to include this external source of organic carbon in biogeochemical models for a better constraining of the carbon budget.

\section{Introduction}

Marine dissolved organic matter (DOM) is the largest reservoir of reduced carbon in the ocean. Estimated at $662 \mathrm{Pg} \mathrm{C}$, which is comparable to that present as atmospheric $\mathrm{CO}_{2}$, DOM plays a key role in the ocean carbon cycle as it is an important pathway of carbon export (Hansell et al., 2009; Moran et al., 2016). At the global scale, dissolved organic carbon (DOC) export from the surface to the deep ocean contributes to $20 \%$ of the total organic carbon flux (Hansell et al., 2009). This percentage reaches more than $50 \%$ of the total carbon export in the oligotrophic oceans (Carlson et 
al., 1994; Guyennon et al., 2015; Letscher and Moore, 2015; Roschan and DeVries, 2017; Bif et al., 2018).

Nutrient availability and microbial community structure regulate the accumulation and the remineralization of DOM, thus influencing the DOC export efficiency (Carlson et al., 2002; Letscher and Moore; 2015; Romera-Castillo et al., 2016). From extensive field studies, it is well known that DOM flux into heterotrophic bacteria is a major pathway in the regulation of carbon fluxes in the ocean (i.e., Azam et al., 1983; Moran et al., 2016). Heterotrophic bacteria are an especially important component of marine oligotrophic regions in which their biomass is comparable to that of phytoplankton. In such oligotrophic areas, half of oceanic primary production is channeled via heterotrophic bacteria to the microbial loop (Fuhrman, 1992; Azam, 1998), driving a wide range of biogeochemical processes that are important for the carbon cycle (Bunse and Pinhassi, 2017; Gasol and Kirchman, 2018, and references therein). Among these processes, the microbial activity has been identified as involved in the alteration of the chemical composition of the DOM pool, thereby influencing the residence time of the carbon in the ocean (Microbial carbon pump, Jiao et al., 2010).

The open ocean receives a continuous flux of anthropogenic particles from the atmosphere, resulting from both industrial and agricultural activities, as well as pulsed fluxes of natural origin such as desert dust (De Leeuw et al., 2014, and references therein). During their transport to the ocean, dust particles mix with anthropogenic aerosols and gas, supplying the water column with a wide variety of compounds including macro- and micronutrients (N, P, Fe, etc.) (Duce et al., 1991; Jickells et al., 2005), as well as potentially toxic elements (Paytan et al., 2009; Jordi et al., 2012). By bringing new nutrients to the upper waters, atmospheric deposition plays a key role in some oligotrophic regions such as the Mediterranean Sea and the northern Atlantic and Pacific gyres, particularly under stratified conditions (Guieu et al., 2014; Letelier et al., 2019). The relative response of phytoplankton and heterotrophic bacteria to dust deposition has been shown to depend on the nutritional status of the environment in which they develop. Indeed, the reported positive effect of dust deposition on primary production in the central Atlantic Ocean decreased with increasing oligotrophy of the seawater (Maranon et al., 2010), suggesting a competitive advantage of heterotrophic bacteria over phytoplankton in the oligotrophic ocean. Nevertheless, recently, the contrasted influence of Saharan dust versus anthropogenic aerosols on bacterioplankton composition and metabolism has been getting attention (Herut et al., 2016; Marín et al., 2017a).

Most studies on the biogeochemical role of atmospheric deposition have focused on the potential of inorganic compounds to relieve nutrient limitation (Duce et al., 1991; Guieu et al., 2014). However, there is increasing evidence that a significant fraction of atmospheric deposition occurs as organic forms (Duce et al., 2008; Kanakidou et al., 2012; Djaoudi et al., 2018; Violaki et al., 2018; Vila-Costa et al., 2019). The extent of organic compounds coating onto dust has been related, among others, to the transport pathway and the reactivity of organic species in the atmosphere (Falkovich et al., 2004; Dall'Osto et al., 2010; Theodosi et al., 2018). Therefore, dust has been considered an excellent medium of longrange transport of organic matter (Falkovich et al., 2004).

Despite that several studies highlighted the positive influence of atmospheric deposition of inorganic nutrients on microbial activity (i.e., Pulido-Villena et al., 2008, 2010; Tsagaraki et al., 2017), there is a paucity of information regarding the bioavailability of atmospheric organic carbon and its fate in the ocean (Djaoudi et al., 2018). In this context, we here investigate the bioavailability to marine heterotrophic bacteria of dissolved organic carbon (DOC) leached from aerosols. For this purpose, we performed a set of in vitro biodegradation experiments in which a marine bacterial inoculum was exposed to water-soluble fractions of anthropogenic and Saharan dust aerosols, as well as to glucose-amended and non-amended (control) treatments.

\section{Material and methods}

\subsection{Aerosol sampling}

Anthropogenic and Saharan dust aerosols were collected on Pall Flex ${ }^{\circledR}$ tissue-quartz pre-combusted $\left(450^{\circ} \mathrm{C}, 6 \mathrm{~h}\right)$ filters $\left(20.3 \times 25.4 \mathrm{~cm}^{2}\right)$, by using high-volume samplers (Tisch Environmental Inc., OH, USA). Anthropogenic aerosols were collected during March 2016, in an urban zone in Marseille (southeast of France: $43.3^{\circ} \mathrm{N}, 5.4^{\circ} \mathrm{E}$; Fig. 1), for $15 \mathrm{~d}$ with an average flow rate of $1.42 \mathrm{~m}^{3} \mathrm{~min}^{-1}$ (Fig. 1). Saharan dust aerosols were collected during June 2016 close to Medenine (southeast of Tunisia: $33.3^{\circ} \mathrm{N}, 10.5^{\circ} \mathrm{E}$; Fig. 1), a major source of desert dust to the Mediterranean Sea (Prospero et al., 2012), over periods of $24 \mathrm{~h}$ with an average flow rate of $0.7 \mathrm{~m}^{3} \mathrm{~min}^{-1}$ (Fig. 1). High-volume samplers were calibrated for flow rate just before sampling. Aerosol filters were individually wrapped in a double pre-combusted aluminum foil and then stored at $-20^{\circ} \mathrm{C}$ until the start of the experiment.

The content of total organic carbon (TOC) in collected aerosols was analyzed using a thermo-optical method (EC/OC analyzer, Sunset Laboratories Inc.) on the basis of EUSAAR protocol (Cavalli et al., 2010). The amount of DOC contained in the water-soluble fraction of both anthropogenic and Saharan dust aerosols was assessed by leaching $1 \mathrm{~cm}^{2}$ of filters in $30 \mathrm{~mL}$ of ultrapure water. After sonication during $40 \mathrm{~min}$, it was filtered through a pre-combusted $\left(450^{\circ} \mathrm{C}, 6 \mathrm{~h}\right) \mathrm{GF} / \mathrm{F}$ filter prior to analysis.

\subsection{Experimental design}

Bioassay experiments were run in triplicates $(7 \mathrm{~L}$ each) on DOC-free artificial seawater in order to set aerosol-derived DOC as the sole carbon source for marine heterotrophic 


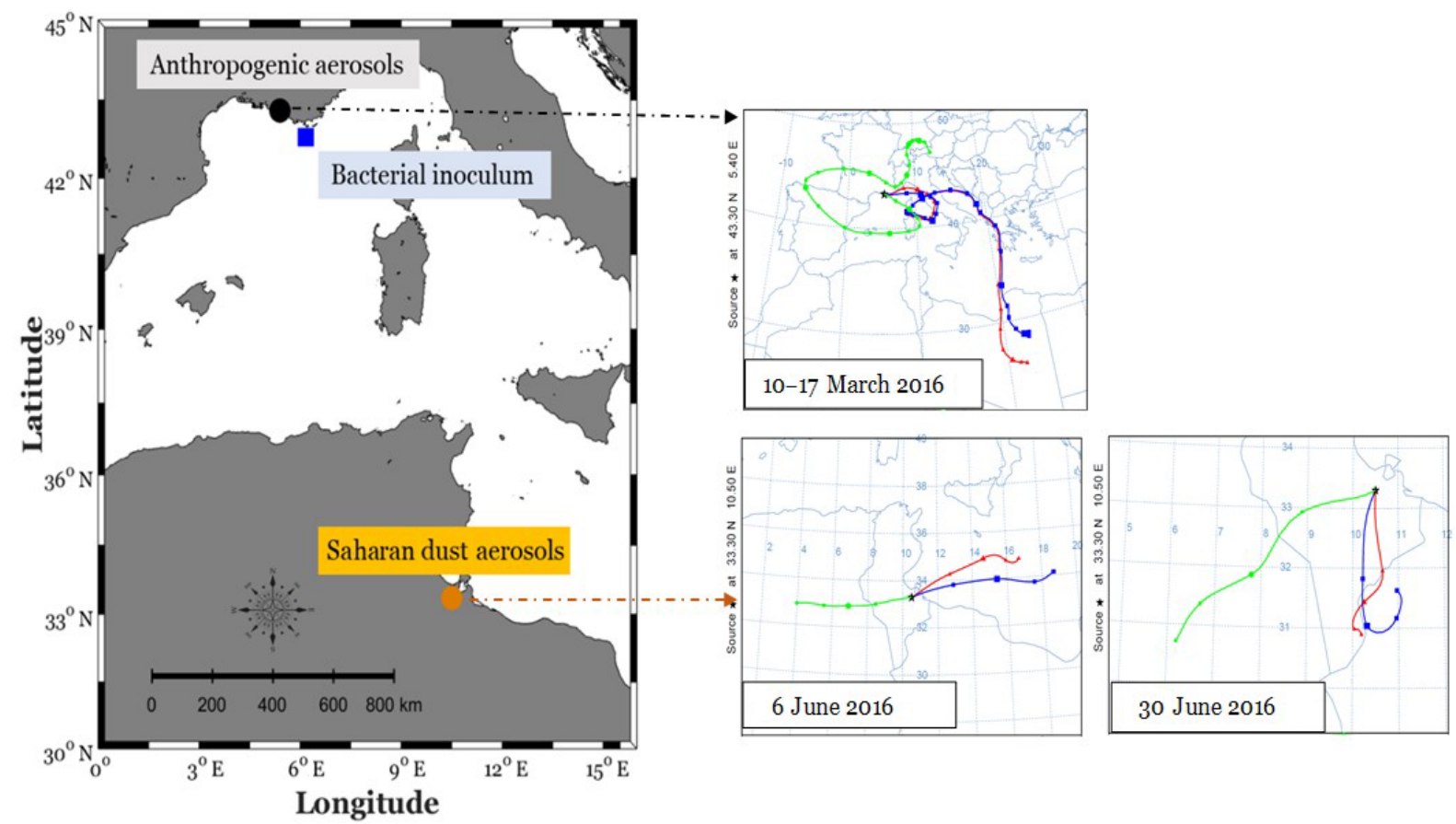

Figure 1. Sampling stations for anthropogenic aerosols (Marseille, southeast of France) and Saharan dust aerosols (Medenine, southeast of Tunisia), as well as for bacterial inoculum (MOOSE-Antares offshore station in the northwestern Mediterranean Sea). Backward air mass trajectories are represented for the periods during which anthropogenic (10-17 March 2016) and Saharan dust aerosols (6 and 30 June 2016) were sampled, using the HYSPLIT trajectory model (https://www.ready.noaa.gov/hypub-bin/trajtype.pl?runtype=archive, last access: 27 April 2020).

bacteria. Artificial seawater was obtained by adding precombusted $\mathrm{NaCl}\left(450^{\circ} \mathrm{C}, 6 \mathrm{~h}\right)$ in ultrapure water to get a salinity of $36 \mathrm{~g} \mathrm{~L}^{-1}$. The DOC concentration in the artificial seawater was $6 \mu \mathrm{M}$ (see Sect. 2.3 for the analytical method).

The experiment consisted of three treatments differing on the carbon source at a similar initial concentration. Experimental treatments were amended with Saharan dust (D), anthropogenic aerosols (A), and glucose $(\mathrm{G})$ as a proxy of bioavailable carbon sources. An unamended DOC treatment (control; C) was run in parallel and consisted only of artificial seawater. As the amount of DOC in the water-soluble fraction was lower in Saharan dust than anthropogenic aerosols (Table 1), the amount of aerosol added was set based on the $\mathrm{C}$ content in Saharan dust aerosol filter in order to fix a similar initial DOC concentration among all amended incubation bottles $(36 \mu \mathrm{M})$. To do so, particles from two whole Saharan dust filters and from $7.9 \times 7.9 \mathrm{~cm}^{2}$ of the anthropogenic aerosol filter were firstly leached, each in $650 \mathrm{~mL}$ ultrapure water. After being sonicated for $40 \mathrm{~min}$, the suspended particles were filtered through pre-combusted GF/F filters $\left(450^{\circ} \mathrm{C}, 6 \mathrm{~h}\right)$ to recover the dissolved fraction. A volume of $200 \mathrm{~mL}$ of each leachate was finally introduced in the corresponding aerosol-amended treatments (D and A). Thus, this protocol simulated an input of atmospheric water-soluble organic carbon through aerosol wet deposition, i.e., an input
Table 1. Total organic carbon (TOC) and dissolved organic carbon (DOC) content in anthropogenic and Saharan dust aerosols used for bacterial incubations.

\begin{tabular}{lrrr}
\hline Aerosols & $\begin{array}{r}\text { TOC } \\
\left(\mathrm{g} \mathrm{C} \mathrm{g}^{-1}\right. \\
\text { aerosol })\end{array}$ & $\begin{array}{r}\text { DOC } \\
\left(\mathrm{g} \mathrm{C} \mathrm{g}^{-1}\right. \\
\text { aerosol })\end{array}$ & $\begin{array}{r}\text { Water } \\
\text { solubility } \\
(\%)\end{array}$ \\
\hline Anthropogenic & 0.155 & 0.05 & 32 \\
Dust & 0.063 & 0.008 & 13 \\
\hline
\end{tabular}

of atmospheric DOC. The same DOC concentration $(36 \mu \mathrm{M})$ was also set for the glucose treatment.

To avoid nutrient limitation, artificial seawater was enriched with nitrogen $\left(\mathrm{NH}_{4} \mathrm{Cl}+\mathrm{NaNO}_{3}\right)$ and phosphate $\left(\mathrm{KH}_{2} \mathrm{PO}_{4}\right)$, to final concentrations of 1 and $0.3 \mu \mathrm{M}$ in the incubation bottles, respectively. Therefore, initial nutrient concentrations in the control and glucose treatments were $1.02 \pm 0.02$ and $1.02 \pm 0.05 \mu \mathrm{M}$ for nitrogen, respectively, and, $0.29 \pm 0.01$ and $0.27 \pm 0.02 \mu \mathrm{M}$ for phosphorus. However, in anthropogenic and dust treatments, aerosol amendments increased nutrient concentrations in the incubation bottles, reaching $6.02 \pm 0.34$ in Saharan dust treatment and $7.03 \pm 0.09 \mu \mathrm{M}$ in anthropogenic treatment for nitrogen concentration and similarly reaching $0.40 \pm 0.02$ in Saharan dust 
treatment and $0.34 \pm 0.01 \mu \mathrm{M}$ in anthropogenic treatment for phosphorus concentration.

A microbial inoculum was introduced in all incubation bottles. To prepare the microbial inoculum, surface seawater was collected at $5 \mathrm{~m}$ depth with a Niskin bottle at the MOOSE-Antares offshore station in the Mediterranean Sea $\left(42^{\circ} 48^{\prime} \mathrm{N}, 6^{\circ} 10^{\prime} \mathrm{E}\right.$; Fig. 1), on board R/V Téthys II. Seawater was first filtered on board through a $40 \mu \mathrm{m}$ mesh plankton and then through $0.8 \mu \mathrm{m}$ pre-cleaned $(10 \% \mathrm{HCl}$ and ultrapure water) polycarbonate filter to remove larger particles and plankton. Once in the laboratory, the microbial inoculum was further concentrated 30 times on a $0.2 \mu \mathrm{m}$ pre-cleaned $(10 \% \mathrm{HCl}$ and ultrapure water) polycarbonate filter in a final volume of $180 \mathrm{~mL}$. The DOC concentration in the $180 \mathrm{~mL}$ inoculum was $120 \mu \mathrm{M}$. A volume of $15 \mathrm{~mL}$ of the bacterial inoculum was added to each experimental bottle. This approach minimizes the volume of seawater (and therefore the amount of DOC) added to the experimental bottles with the microbial inoculum (Lechtenfeld et al., 2015), allowing us to set the aerosol-derived DOC as the main carbon source for heterotrophic bacteria. After dilution in the incubated volume $(7 \mathrm{~L})$, the contribution of marine DOC was $<0.3 \mu \mathrm{M}$. All experimental bottles were incubated in a controlled temperature room at $18^{\circ} \mathrm{C}$ for $16 \mathrm{~d}$ in the dark and were regularly gently shaken.

\subsection{Subsampling and analyses}

Subsamples were collected from the experimental bottles at 13 selected times for heterotrophic bacterial abundance (BA) and heterotrophic bacterial production (BP) and at three selected times for ectoenzymatic activity (EEA), dissolved organic carbon (DOC), dissolved organic nitrogen (DON), and dissolved organic phosphorus (DOP) (see Table S1 in the Supplement for details of subsampling).

Samples for BA $(1.8 \mathrm{~mL})$ were fixed with $18 \mu \mathrm{L}$ of a preservative solution (glutaraldehyde $0.25 \%$ final - pluronic $0.01 \%$ final), kept for $15 \mathrm{~min}$ at room temperature in the dark and then transferred to a $-80^{\circ} \mathrm{C}$ freezer until analysis, within a few days. Frozen samples were thawed at room temperature and were analyzed using the FACSCalibur (BD Biosciences) flow cytometer (PRECYM flow cytometry platform, http://precym.mio.univ-amu.fr, last access: 24 November 2020). For BA cell counts, samples $(0.3 \mathrm{~mL})$ were incubated with SYBR Green II solution 1:10 (2 $\mu \mathrm{L}$, Molecular Probes) for $15 \mathrm{~min}$ in the dark, in order to stain the nucleic acids. Each cell was characterized by three optical parameters: light diffusion parameter side-scatter (SSC), green fluorescence $(515-545 \mathrm{~nm}$; SYBRgreen), and red fluorescence (670 LP; chlorophyll $a$, in order to exclude autotrophic prokaryotes). Combining SYBRGreen fluorescence and SSC allowed us to distinguish the cells from inorganic particles, detritus, and free DNA (Marie et al., 2002). Data were processed using the CellQuest software (BD Biosciences), and BA was further determined using Summit 4.3 software (Beckman Coulter).

BP was estimated by ${ }^{3} \mathrm{H}$-leucine incorporation applying the centrifugation method (Smith and Azam, 1992). Samples $(1.5 \mathrm{~mL})$ were incubated in the dark between 1 and $6 \mathrm{~h}$ at $18^{\circ} \mathrm{C}$ with a mixture of ${ }^{3} \mathrm{H}$-leucine (Perkin Elmer ${ }^{\circledR}$ specific activity $106 \mathrm{Ci} \mathrm{mmol}^{-1}$ ) and non-radioactive leucine to a final concentration of $20 \mathrm{nM}\left(6 \mathrm{nM}{ }^{3} \mathrm{H}\right.$-leucine $+14 \mathrm{nM}$ cold leucine) in $2 \mathrm{~mL}$ Eppendorf tubes. Incorporations were stopped by addition of trichloroacetic acid (TCA) to a final concentration at $5 \%$. The control was prepared for each treatment by the addition of TCA, before the addition of ${ }^{3} \mathrm{H}$-leucine. Samples were then centrifuged for $10 \mathrm{~min}$ at $16000 \mathrm{~g}$ three times, first with the fixed sample, second with TCA $5 \%$, and finally with ethanol $80 \%$. After resuspension of the pellet in $1.5 \mathrm{~mL}$ scintillation liquid (Ultima Gold MV), radioactivity was determined by a liquid scintillation counter. Leucine incorporation rates were converted into carbon production using the conversion factors of $1.5 \mathrm{~kg} \mathrm{C}$ per mole of leucine incorporated (Kirchman, 1993).

EEAs were measured fluorometrically, using two fluorogenic model substrates, 4-methylumbelliferyl $-\beta \mathrm{D}$ glucopyranoside (MUF- $\beta$ glu) and L-leucine-7-amido-4methyl-coumarin (Leu-MCA) as representative of $\beta$ glucosidase and aminopeptidase, respectively (Hoppe, 1983). Hydrolysis rates were determined by incubating in black 24 microtiter-plate $2 \mathrm{~mL}$ of the $\mathrm{D}$ and A treatments with six $(0.05,0.2,1,2,5$, and $10 \mu \mathrm{M})$ concentrations of each substrate model. To ensure linearity of the hydrolysis rate, the increase in fluorescence was measured at multiple time points during the incubation period (ex/em: $380 / 440 \mathrm{~nm}$ for MCA and $365 / 450 \mathrm{~nm}$ for MUF, wavelength width $5 \mathrm{~nm}$ ) in a Varioskan LUX microplate reader. The instrument was calibrated with standards of MCA and MUF solutions diluted in $<0.2 \mu \mathrm{m}$ filtered seawater.

Samples for DOC analysis $(10 \mathrm{~mL})$ were filtered in line, through pre-combusted $\left(450^{\circ} \mathrm{C}, 6 \mathrm{~h}\right) 47 \mathrm{~mm} \mathrm{GF} / \mathrm{F}$ filters. The filtrates were then transferred into pre-combusted glass tubes where $50 \mu \mathrm{L}$ of phosphoric acid $\left(\mathrm{H}_{3} \mathrm{PO}_{4}, 85 \%\right)$ was added. The glass tubes were sealed and stored in the dark at $4{ }^{\circ} \mathrm{C}$ until analysis. DOC was analyzed using the hightemperature catalytic oxidation (HTCO) technique with a Shimadzu TOC-V analyzer. The daily calibration curve was based on four standard solutions $(0,50,100$, and $150 \mu \mathrm{M})$ of potassium acid phthalate $\left(1000 \mathrm{n} \mathrm{L}^{-1}\right)$. The analytical precision of the procedure, based on three to five injections and analysis of the same sample, was $1.8 \%$ on average. The accuracy of the instrument was determined by the analysis of a deep-seawater reference provided by the Hansell CRM program (Hansell, 2005). The average DOC concentration in the deep-seawater reference was $45 \pm 3 \mu \mathrm{M}$.

DON and DOP were determined after subtraction of the dissolved inorganic fraction of nitrogen (DIN) and phosphorus (DIP) from the total dissolved fractions (TDN and TDP), respectively. Samples for TDN, TDP, DIP, and DIN (60 mL) 
were filtered online through pre-cleaned $(\mathrm{HCl} 10 \%$ and ultrapure water) $47 \mathrm{~mm} 0.2 \mu \mathrm{m}$ polycarbonate filters and then transferred into precleaned ( $\mathrm{HCl} 10 \%$ and ultrapure water) $60 \mathrm{~mL}$ HDPE bottles. Samples were kept frozen $\left(-20^{\circ} \mathrm{C}\right)$ until analysis through the conventional automated colorimetric procedure (Aminot and Kerouel, 2007). Prior to analysis, TDN and TDP were submitted to a wet oxidation according to Pujo-Pay and Raimbault (1994). The detection limits for DIN $\left(\mathrm{NO}_{3}^{-}+\mathrm{NO}_{2}^{-}\right)$and DIP $\left(\mathrm{PO}_{4}^{3-}\right)$ analysis were 0.05 and $0.02 \mu \mathrm{M}$, respectively.

\subsection{Determination of labile DOC, bacterial growth efficiency, and kinetic parameters}

The percentage of the labile dissolved organic carbon (LDOC) was calculated as

$\operatorname{LDOC}(\%)=\frac{[\mathrm{DOC}]_{\text {initial }}-[\mathrm{DOC}]_{\text {Final }}}{[\mathrm{DOC}]_{\text {initial }}} \cdot 100$.

Bacterial growth efficiency (BGE, \%) was calculated by dividing the time-integrated $\mathrm{BP}$ by the corresponding labile fraction of DOC (LDOC).

$\operatorname{BGE}(\%)=\frac{\text { time }- \text { integrated BP }}{[\text { LDOC }]} \cdot 100$

Maximum hydrolysis rate $\left(V_{\max }\right)$ and Michaelis-Menten constant $\left(K_{\mathrm{m}}\right)$ were determined by fitting the EEA data using a nonlinear regression on the rectangular hyperbolic function following

$V=V_{\max } \frac{S}{K_{\mathrm{m}}+S}$,

where $V$ is the MUF- $\beta$ glu or MCA-leu hydrolysis rate and $\mathrm{S}$ the concentration of the fluorogenic substrate.

\subsection{Statistics}

The three-replicate average values of bacterial activity (BA, $\mathrm{BP}$, and EEA) and nutrient concentrations (DOC, DON, and DOP) in the G, D, A, and C treatments were compared, over the incubation period, using a one-way ANOVA statistical test. ANOVA returns a $p$ value higher than 0.05 for the null hypothesis that the means of the different studied treatments are equal.

\section{Results}

\subsection{Total and dissolved organic carbon}

The content of TOC in aerosols and of DOC in the watersoluble fractions was higher in anthropogenic (0.155 and $0.05 \mathrm{~g} \mathrm{C} \mathrm{g}^{-1}$ aerosol, respectively) than in Saharan dust aerosols (0.063 and $0.008 \mathrm{~g} \mathrm{C} \mathrm{g}^{-1}$ aerosol, respectively) (Table 1). Likewise, the dissolved fraction resulting from leaching was higher in the anthropogenic aerosols (32\%) than
Table 2. Initial dissolved organic carbon concentration and its decrease and contribution to the initial DOC stocks (expressed as a percentage of labile dissolved organic carbon, LDOC). In the control treatment, LDOC was calculated between $T_{5.7}$ and $T_{\text {final }}$.

\begin{tabular}{lrrr}
\hline & $\begin{array}{r}\text { Initial DOC; } \\
\mu \mathrm{mol} \mathrm{C} \mathrm{L}\end{array}$ & $\begin{array}{r}\text { DOC decrease; } \\
\mu \mathrm{mol} \mathrm{C} \mathrm{L}^{-1}\end{array}$ & LDOC (\%) \\
\hline C1 & 14 & 5 & 23 \\
C2 & 14 & 6 & 27 \\
C3 & 12 & 4 & 22 \\
\hline Mean $( \pm$ SD $)$ & $14 \pm 1$ & $5 \pm 1$ & $24 \pm 3$ \\
\hline G1 & 36 & 19 & 53 \\
G2 & 42 & 24 & 57 \\
G3 & 41 & 22.5 & 54 \\
\hline Mean $( \pm$ SD $)$ & $40 \pm 3$ & $22 \pm 3$ & $55 \pm 2$ \\
\hline A1 & 34 & 6 & 17 \\
A2 & 37 & 11 & 29 \\
\hline Mean $( \pm S D)$ & 36 & 9 & 24 \\
\hline D1 & 31 & 7 & 22 \\
D2 & 36 & 8.5 & 24 \\
D3 & 36 & 11 & 30 \\
\hline Mean $( \pm S D)$ & $34 \pm 3$ & $9 \pm 2$ & $25 \pm 4$ \\
\hline
\end{tabular}

in Saharan dust (13\%) (Table 1). About $1 \mathrm{~h}$ after aerosol amendments $\left(T_{0}\right)$, the measured initial concentration of DOC in the control treatment $(14 \pm 1 \mu \mathrm{M})$ was higher than the expected value of $6.3 \mu \mathrm{M}$ (DOC concentration in artificial seawater + inoculum; see the Method section). This "extra DOC" was not observed in the amended treatments, where concentrations of $40 \pm 3,36$, and $34 \pm 3 \mu \mathrm{M}$ were observed in the $\mathrm{G}, \mathrm{A}$, and $\mathrm{D}$ treatments, respectively, consistent with the amount of DOC added through amendments $(36 \mu \mathrm{M}$ final concentration in the incubation bottles; see the Method section) (Table 1). Over the incubation period $\left(T_{0}-T_{\text {final }}\right)$, DOC concentration decreased in the three amended treatments (Fig. 2a). This decrease was highest in the $G$ treatment $(22 \pm 2 \mu \mathrm{M})$ followed by both the $\mathrm{D}(9 \pm 2 \mu \mathrm{M})$ and $\mathrm{A}(9 \mu \mathrm{M})$ treatments (Table 2; Fig. 2a). In the $\mathrm{C}$ treatment, a net decrease in DOC, of $5 \pm 1 \mu \mathrm{M}$, was detected only after $T_{5.7}$ (between $T_{5.7}$ and $\left.T_{\text {final }}\right)$. As no extra DOC was observed in the $\mathrm{G}, \mathrm{A}$, and D treatments, the variation in DOC in the control was not taken into consideration in the calculation of labile DOC in the G, D, and A treatments. Therefore, the resulting labile DOC fractions were $55 \pm 2 \%, 25 \pm 4 \%$, and $24 \pm 8 \%$ in the $\mathrm{G}, \mathrm{D}$, and $\mathrm{A}$ treatments, respectively (Table 2).

\subsection{Dissolved organic nitrogen and phosphate}

The initial DON and DOP concentrations in the $\mathrm{C}$ treatment were $1.6 \pm 0.1 \mu \mathrm{M}$ and below the detection limit, respectively. The G treatment exhibited the same initial DON concentration as the $\mathrm{C}$ treatment, with values of $1.8 \pm 0.2 \mu \mathrm{M}$ 
(a)
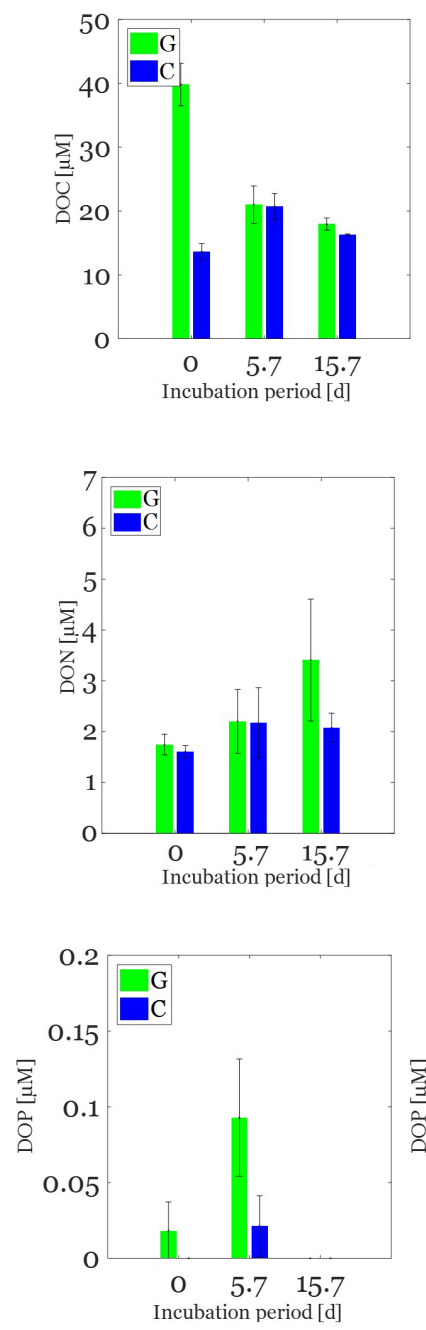

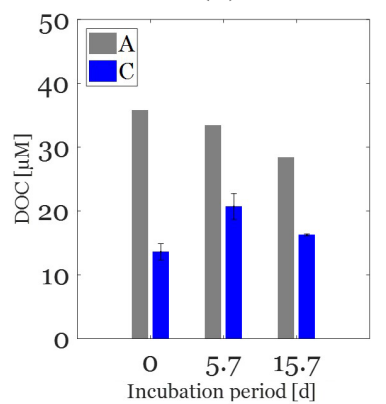

(b)

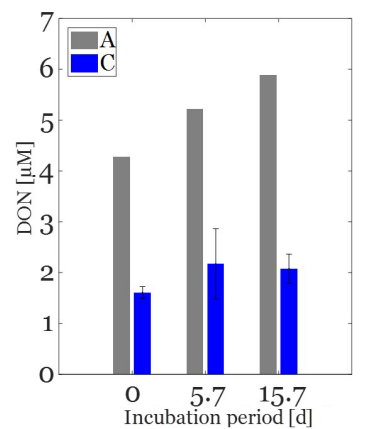

(c)
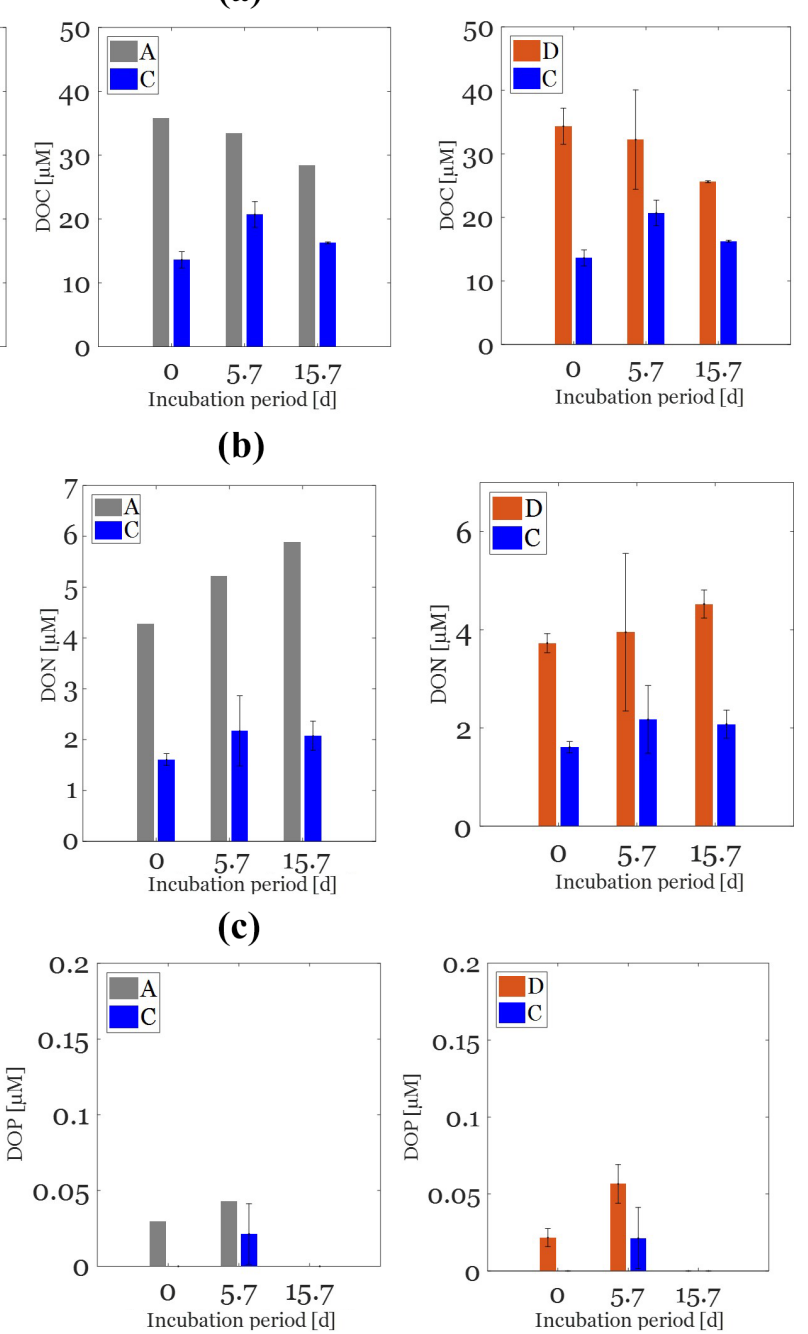

Figure 2. Changes in dissolved organic carbon (DOC, a), nitrogen (DON, b), and phosphate (DOP, c) concentrations over the incubation period in glucose (left, green bars), anthropogenic aerosols (middle, gray bars), and Saharan dust aerosols (right, orange bars). The control is plotted in each panel (blue bars).

while DOP concentrations reached $0.03 \pm 0.01 \mu \mathrm{M}$ (Fig. 2b, c). In the $\mathrm{A}$ and $\mathrm{D}$ treatments, the concentration of both DON and DOP increased immediately after aerosol addition $\left(T_{0}\right)$. The DON concentration reached 4.3 and $3.7 \pm 0.2 \mu \mathrm{M}$ in the A and D treatments, respectively (Fig. 2a), resulting in lower $\mathrm{C}: \mathrm{N}$ and higher $\mathrm{N}: \mathrm{P}$ elemental ratios in the $\mathrm{A}$ and $\mathrm{D}$ treatments than in the $\mathrm{G}$ treatment (Table S2). The increase in DOP after aerosol addition in the D treatment was of $0.02 \pm 0.005 \mu \mathrm{M}$ and was similar to that observed in the $\mathrm{G}$ treatment. In the A treatment, the increase in DOP was slightly higher, reaching a value of $0.04 \mu \mathrm{M}$ (Fig. 2b), which resulted in lower $C: P$ ratios in $A$ than in both $D$ and $G$ in the beginning of the experiment (Table S2).

In all treatments, over the incubation period, DON concentrations remained constant while DOP concentrations exhibited a significant increase between $T_{0}$ and $T=5.7 \mathrm{~d}$, to finally decrease to values below the detection limit at the end of the incubation period (Fig. 1b and c). Over the incubation period, $\mathrm{C}: \mathrm{N}$ elemental ratios decreased slightly in the A (ANOVA; $p<0.05 ; F=5.3 ; \mathrm{df}=5$ ) and $\mathrm{G}$ (ANOVA; $p<0.05 ; F=31.5 ; \mathrm{df}=8)$ treatments while they remained constant in the D (ANOVA; $p>0.05 ; F=0.1 ; \mathrm{df}=8$ ) and $\mathrm{C}$ (ANOVA; $p>0.05 ; F=0.5 ; \mathrm{df}=8$ ) treatments (Table $\mathrm{S} 2$ ). In contrast, $\mathrm{C}: \mathrm{P}$ and $\mathrm{N}: \mathrm{P}$ elemental ratios were similar in the A treatment while they decreased significantly in both the $\mathrm{D}$ and $\mathrm{G}$ treatments (Table S2).

\subsection{Microbial activity over the incubation period}

In all the experimental bottles, an increase in both bacterial abundance (BA) and bacterial production (BP) was observed during the incubation time. One replicate from the A treatment diverged completely from the other replicates (it did not 
show any bacterial growth and BP fluxes collapsed suddenly on day 6) and it was excluded from the data processing.

At the beginning of the incubations $\left(T_{0}\right)$, BA was similar in all treatments (ANOVA; $p>0.05 ; F=0.64$; df $=10$ ), with an average value of $2.3 \pm 0.1 \times 10^{5}$ cells $\mathrm{mL}^{-1}$ (Fig. 3a). After $1.7 \mathrm{~d}$ of incubation, BA exhibited a 3 -fold decrease in all treatments. Following this decrease, a lag time phase was observed, during which BA continued to decrease slowly in all treatments. This lag phase period was longer in the $\mathrm{C}$ treatment $(7.7 \mathrm{~d})$, followed by both the A and D treatments $(5.7 \mathrm{~d})$ and finally by the $\mathrm{G}$ treatment (3.7 d; Fig. 3a). After that period, an exponential growth of BA was observed first in the $G$ treatment, followed then by both the A and D treatments and finally by the $\mathrm{C}$ treatment (Table 3 ). During that exponential growth period, BA reached similar values (ANOVA; $p=$ $0.34 ; F=1.31 ; \mathrm{df}=10)$ in the $\mathrm{G}\left(6 \pm 3 \times 10^{5}\right.$ cells $\left.\mathrm{mL}^{-1}\right)$, $\mathrm{A}\left(5 \times 10^{5}\right.$ cells $\left.\mathrm{mL}^{-1}\right)$, and $\mathrm{D}\left(5 \pm 1 \times 10^{5}\right.$ cells $\left.\mathrm{mL}^{-1}\right)$ treatments (Fig. 3a). In the control treatment, until $t=6.7 \mathrm{~d}$, BA remained low, $<0.6 \times 10^{5}$ cells $\mathrm{mL}^{-1}$ and then increased up to $2.5 \pm 0.6 \times 10^{5}$ cells $\mathrm{mL}^{-1}$ during the exponential growth phase (Fig. 3a). At the end of the incubation period, BA continued to increase in all treatments, reaching up to twice the observed BA during the exponential growth phase (Fig. 3a).

Initial BP was low in all experimental bottles, with an average value of $0.042 \pm 0.035 \mathrm{ng} \mathrm{CL}^{-1} \mathrm{~h}^{-1}$ (Fig. 3b). BP started to increase first in the $G$ treatment followed by the D and then A treatments (Fig. 3b; Table 3). Like BA, BP also exhibited an exponential growth phase, which started after a lag phase shorter than that of BA (Table 3). During the exponential growth period (Table 3), BP growth rates were similar in the $G$ and $D$ treatments (ANOVA, $F=6.76 ; p>0.05 ; \mathrm{df}=5$ ) and were significantly higher than in the $\mathrm{A}$ and $\mathrm{C}$ treatments (ANOVA, $F=10.47 ; p<0.05 ; \mathrm{df}=10$ ) (Table 3). Likewise, maxima of BP reached were similar in the D $\left(879 \pm 64 \mathrm{n} \mathrm{C} \mathrm{L}^{-1} \mathrm{~h}^{-1}\right)$ and $\mathrm{G}\left(648 \pm 156 \mathrm{ng} \mathrm{CL}^{-1} \mathrm{~h}^{-1}\right)$ treatments (ANOVA, $F=$ $5.63 ; p>0.05 ; \mathrm{df}=5)$ and were significantly higher (ANOVA, $F=43.4 ; p<0.05 ; \mathrm{df}=10$ ) than in the A $\left(124 \mathrm{ng} \mathrm{C} \mathrm{L}^{-1} \mathrm{~h}^{-1}\right)$ and $\mathrm{C}\left(120 \pm 56 \mathrm{ng} \mathrm{CL}^{-1} \mathrm{~h}^{-1}\right)$ treatments. In the $\mathrm{C}$ treatment, until $t=6.7 \mathrm{~d}$, BP was low $(<$ $\left.2 \mathrm{ng} \mathrm{C} \mathrm{L}^{-1} \mathrm{~h}^{-1}\right)$ and then increased at the end of the incubation period (Fig. 3b).

The Michaelis-Menten fit of aminopeptidase and $\beta$ glucosidase activities was significant only at the end of the incubation period ( $T=15.7 \mathrm{~d}$ ). Thereby, only these data are presented (Fig. S1 in the Supplement). The average aminopeptidase $V_{\mathrm{m}}$ in the $\mathrm{D}$ treatment was $1.3 \pm 0.2 \mathrm{nMh}^{-1}$ and was significantly lower by approximately 4 times (ANOVA, $F=$ 34.3; $p<0.05 ; \mathrm{df}=4)$ than that observed in the A treatment $\left(4.4 \mathrm{nmolh}^{-1}\right) . \beta$-glucosidase $V_{\mathrm{m}}$ was much lower than that of aminopeptidase in both the A and D treatments. Opposite to what was obtained with MCA-leucine, and although not significantly different due to the variability within triplicates (ANOVA, $F=6.24, p>0.05$, df $=4$ ), the average $\beta$-glucosidase $V_{\mathrm{m}}$ was slightly higher in $\mathrm{D}$, with values rang- ing from 0.08 to $0.16 \mathrm{nM} \mathrm{h}^{-1}$ compared to $0.02-0.03 \mathrm{nM} \mathrm{h}^{-1}$ in A. These differences between treatments were still observed considering specific $V_{\mathrm{m}}$ (per bacterial cell, Fig. 4). Indeed, like for volumetric $V_{\mathrm{m}}$ rates, cell-specific aminopeptidase $V_{\mathrm{m}}$ values (Fig. 4) were lower in D than A (ANOVA, $F=650.5 ; p<0.05 ; \mathrm{df}=4)$. Likewise, cell-specific $\beta$ glucosidase $V_{\mathrm{m}}$ showed slightly higher values in $\mathrm{D}(0.06$ $0.16 \times 10^{-18}$ mol cell $\mathrm{L}^{-1} \mathrm{~h}^{-1}$ ) compared to A (range 0.015 $0.026 \times 10^{-18}$ mol cell $\mathrm{L}^{-1} \mathrm{~h}^{-1}$ ), although not significantly different between the two aerosol treatments (Fig. 4). The opposite trend was noticed for $\beta$ glucosidase $K_{\mathrm{m}}$, with lower values in the D (0.06-0.16) than A (0.4-2.3) treatment.

The bacterial growth efficiency (BGE) in the D treatment $(14.2 \pm 5.5 \%)$ compared well with the $\mathrm{G}$ treatment $(7.6 \pm 2 \%)$ (ANOVA, $F=3.9 ; p>0.05 ; \mathrm{df}=5)$, and both were significantly higher than that observed for the A treatment (1.7) (ANOVA, $F=7.91 ; p<0.05$; df =5) (Table 3).

\section{Discussion}

\subsection{Influence of the aerosol source on marine heterotrophic bacterial activity}

In this study, the addition of Saharan dust and anthropogenic aerosols as a sole $\mathrm{C}$ source to marine bacteria stimulated both heterotrophic bacterial abundance (BA) and production (BP), evidencing the bioavailability of aerosol-derived DOC.

However, at the beginning of the experiment, a lag time period was observed in all treatments, during which BA dropped by 3 times its initial value. This consistent decrease in BA may be attributed to a stress of marine heterotrophic bacteria during the preparation of the inoculum and to their contact with a new environment/matrix, containing an unusual source of carbon. Indeed, although a lag time period was also recorded in the $G$ treatment, it was shorter than that in the A and D treatments, which could suggest a non-immediate bioavailability of aerosol organic matter compared to glucose. This non-immediate bioavailability of the dissolved pool of organic matter has been highlighted in the ocean in a review on marine DOM incubation experiments (Lønborg and Alavrez-Salgado, 2012; Sipler and Bronk, 2015, and references therein). Other factors including potential additions of toxic molecules and/or viruses from the aerosol leachate could have exerted a control on marine heterotrophic bacteria at the beginning of the experiment, explaining the observed lag time period.

After the lag phase, an increase in BA and BP was observed first in the $G$ treatment, followed by the $D$ and then $A$ treatment, with bacterial growth rates significantly higher in the $\mathrm{G}$ and $\mathrm{D}$ treatments than in the A treatment. In contrast to Marín et al. (2017b), in which BA and BP exhibited a contrasted response following mineral dust and anthropogenic aerosol addition, the observed increase in both BA and BP in this study was higher in the D treatment than in A. Follow- 
(a)
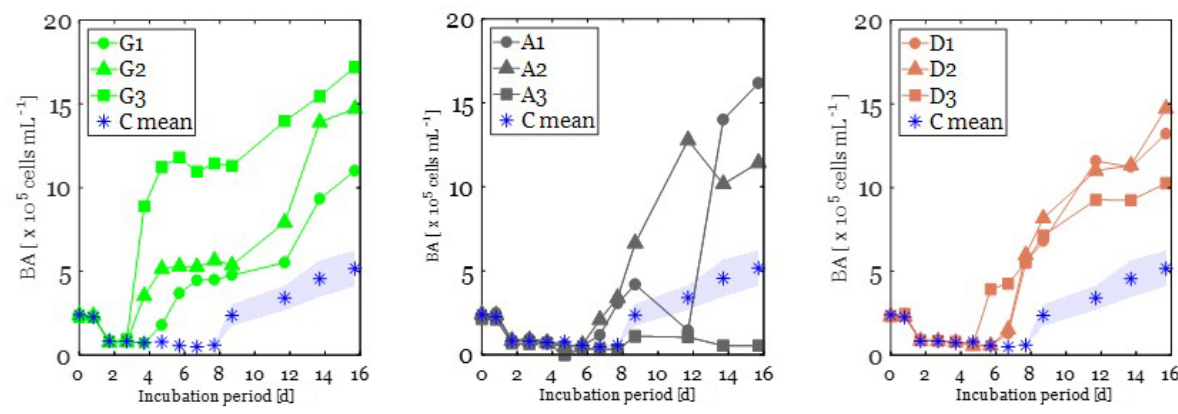

(b)

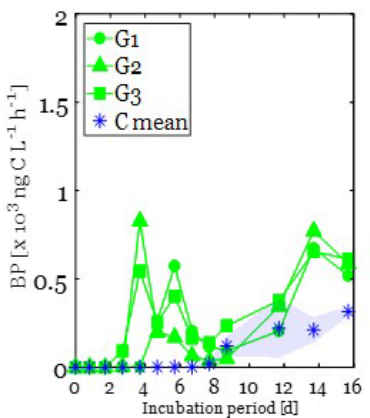

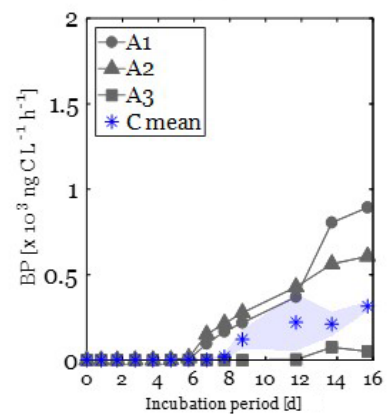

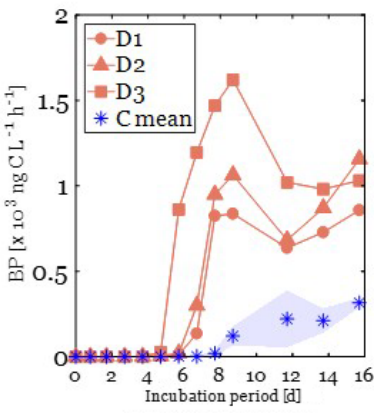

Figure 3. Changes in heterotrophic bacterial abundance (BA; a) and production (BP, b) over the incubation period in glucose (left, green plots), anthropogenic aerosols (middle, gray plots), and Saharan dust aerosols (right, orange plots). The control is plotted in each panel: the average value is represented by the stars and the standard deviation by the bounded lines.

Table 3. Duration of the exponential growth phase for bacterial abundance (BA) and bacterial production (BP), bacterial growth rate ( $\mu$ ) estimated from both BP and BA changes during the exponential growth phase, time-integrated BP during the exponential growth phase, and bacterial growth efficiency (BGE). Data from each triplicate and average ( \pm SD) values are given for the control $(C)$, glucose, anthropogenic, and Saharan dust treatments.

\begin{tabular}{|c|c|c|c|c|c|c|}
\hline Treatments & $\begin{array}{r}\text { Exponential } \\
\text { phase period } \\
\text { for BA (days) }\end{array}$ & $\begin{array}{r}\text { Exponential } \\
\text { phase period } \\
\text { for BP (days) }\end{array}$ & $\begin{array}{r}\mu ;\left(\mathrm{d}^{-1}\right) \\
\text { (estimated } \\
\text { from } \mathrm{BP})\end{array}$ & $\begin{array}{r}\mu ;\left(\mathrm{d}^{-1}\right) \\
\text { (estimated } \\
\text { from BA) }\end{array}$ & 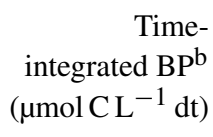 & $\begin{array}{r}\mathrm{BGE}_{\mathrm{BP}} \\
(\%)\end{array}$ \\
\hline $\mathrm{C} 1$ & $7.7-13.7$ & $1.7-8.7$ & $1.23 \pm 0.19$ & $1.41 \pm 0.56$ & 0.23 & 5 \\
\hline $\mathrm{C} 2$ & $6.7-8.7$ & $1.7-8.7$ & $0.94 \pm 0.15$ & $0.86 \pm 0.4$ & 0.11 & 2 \\
\hline $\mathrm{C} 3$ & $6.7-8.7$ & $1.7-8.7$ & $1 \pm 0.13$ & $0.94 \pm 0.55$ & 0.18 & 4.5 \\
\hline Mean $( \pm \mathrm{SD})$ & & & $1.05 \pm 0.15$ & $1.07 \pm 0.39$ & $0.17 \pm 0.06$ & $4 \pm 2$ \\
\hline G1 & $3.7-5.7$ & $0-5.7$ & $1.99 \pm 0.32$ & $1.21 \pm 0.08$ & 1.07 & 5.6 \\
\hline G2 & $2.7-4.7$ & $0.7-3.7$ & $3.44 \pm 0.52$ & $1.25 \pm 0.49$ & 1.87 & 7.8 \\
\hline G3 & $2.7-3.7$ & $0-3.7$ & $3 \pm 0.41$ & $1.3 \pm 0.66$ & 2.16 & 9.6 \\
\hline Mean $( \pm S D)$ & & & $2.81 \pm 0.74$ & $1.25 \pm 0.05$ & $1.70 \pm 0.57$ & $7.6 \pm 2$ \\
\hline A1 & $5.7-8.7$ & $2.7-6.7$ & $1.64 \pm 0.21$ & $1.14 \pm 0.07$ & 0.11 & 1.8 \\
\hline A2 & $4.7-8.7$ & $2.7-6.7$ & $1.62 \pm 0.28$ & $1.37 \pm 0.15$ & 0.19 & 1.7 \\
\hline Mean $( \pm \mathrm{SD})$ & & & 1.63 & 1.25 & 0.15 & 1.7 \\
\hline D1 & $5.7-7.7$ & $2.7-7.7$ & $1.74 \pm 0.09$ & $1.05 \pm 0.19$ & 1.11 & 16.1 \\
\hline D2 & $5.7-7.7$ & $0.7-7.7$ & $1.41 \pm 0.10$ & $1.01 \pm 0.16$ & 1.58 & 18.5 \\
\hline D3 & $4.7-5.7$ & $1.7-5.7$ & $1.80 \pm 0.30$ & $1.10 \pm 0.49$ & 0.88 & 8.1 \\
\hline Mean $( \pm S D)$ & & & $1.65 \pm 0.20$ & $1.05 \pm 0.04$ & $1.19 \pm 0.36$ & $14.2 \pm 5.5$ \\
\hline
\end{tabular}




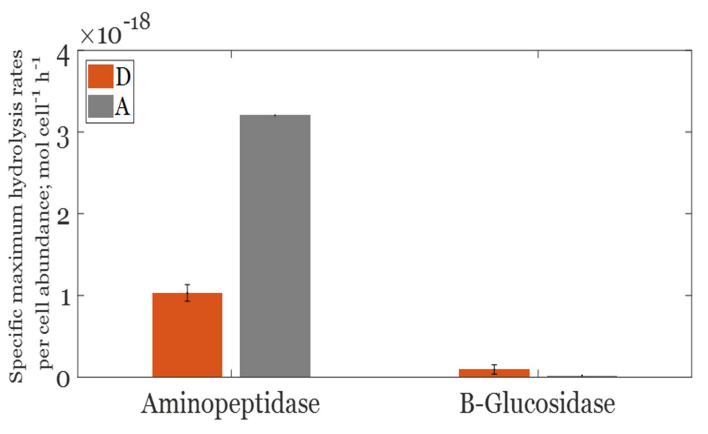

Figure 4. Cell-specific maximum aminopeptidase and $\beta$ glucosidase hydrolysis rates per cell abundance in Saharan dust (orange bars) and anthropogenic (gray bars) aerosol treatments at the end of the incubation period.

ing this increase in bacterial activity, DOC was consumed, highlighting a higher LDOC fraction in the G treatment than in the A and D treatments. In those two treatments, LDOC fractions were quantitatively similar, despite a higher solubility of organic carbon derived from anthropogenic aerosols compared to Saharan dust aerosols. Nevertheless, contrasted metabolic pathways were evolved by marine heterotrophic bacteria in the A and D treatments over the timescale of the incubation period. Indeed, the BGE in the D treatment $(14.2 \pm 5.5 \%)$ compares well with that of the $\mathrm{G}$ treatment $(7.6 \pm 2 \%)$, and both values were significantly higher than that of the A treatment $(1.7 \%)$. This result suggests that, in the experimental conditions of this study, the metabolic use of LDOC in the G and D treatments was energetically equivalent, with evidence of approximatively $1 / 10$ of DOC incorporated going into structural components. In contrast, the carbon consumed in the A treatment was mostly catabolized. The use of BP in the calculation of BGE could be biased as BP is determined using a leucine-to-carbon conversion factor. However, in this study, we still preferred using $\mathrm{BP}$ rather than BA in this calculation, as BA could also be subjected to a number of biases. Indeed, the determination of BGE using BA requires the utilization of an abundancebiomass conversion factor, and yet biovolume varies substantially during the growth. Furthermore, the variation in cell abundance is the result of a net balance between growth and mortality. This is visible through observations of apparent growth rates, calculated from exponential growth phases of both BP and BA (Table 3), lower for BA than BP. Likewise, this is also visible regarding the lag phase, shorter for $\mathrm{BP}$ than BA (Table 3). This is a classical issue occurring during dilution experiments for BGEs but also leucine conversion factor determinations (Kirchman et al., 1982; Ammerman et al., 1984).

The factors controlling whether organic carbon is catabolized or incorporated into microbial biomass are still poorly resolved. Nevertheless, the conversion of carbon into biomass only occurs after non-growth requirements have been satisfied and sufficient excess of carbon and energy is available (Del Giorgio and Cole, 1998). To explain the differences in BGE observed in this study among glucose, Saharan dust, and anthropogenic aerosol amendments, several hypotheses can be proposed (see below).

\subsection{Potential controlling factors of the bacterial growth efficiency}

A number of parameters were controlled at the beginning and/or during the incubation period and can thus be reasonably excluded. Indeed, temperature and initial microbial inoculum were equal among all treatments. Since DIN and DIP were added in excess, $\mathrm{N}$ and $\mathrm{P}$ availability were not growth limiting over the incubation period. Alongside those nutrient enrichments, aerosol amendments resulted in initial $\mathrm{N}$ concentrations up to $7 \mu \mathrm{M}$ ( 6 and $7 \mu \mathrm{M}$ in D and A, respectively) and initial $\mathrm{P}$ concentrations up to $0.4 \mu \mathrm{M}(0.40$ and $0.34 \mu \mathrm{M}$ in D and A, respectively). Different BGE values were observed between the D and A treatments despite similar initial nutrient concentration. Moreover, BGE in D was similar to that of the $\mathrm{G}$ treatment despite a higher nutrient concentration, suggesting that inorganic nutrients were weakly involved in the control of BGE.

Conversely, DOM composition or quality and/or micronutrient availability (i.e., Fe, Zn) may have influenced the BGE in the A and D aerosol treatments, as they are reported as the main variables controlling the BGE in fresh and marine waters (Fenchel and Blackburn, 1979; Biddanda et al., 1994; Carlson and Ducklow, 1996; Kirchman, 2018, and references therein).

In this study, BGE was lower in A than in both the $\mathrm{D}$ and $\mathrm{G}$ treatments, which could suggest a DOM pool of a lower quality in anthropogenic aerosols with respect to Saharan dust. The observed differences in ectoenzymatic activities between the D and A treatments support this hypothesis. The higher cell-specific aminopeptidase activity in the A treatment combined with its enzymatic system adapted to low concentrations (low $K_{\mathrm{m}}$ ) presumably suggest a lower bacterial access to amino acids despite a higher DON concentration in A than in the D treatment. Thus, the versatility in catabolic enzymatic synthesis was probably limited due to less access to amino acids, contributing to the observed low BGE in the A treatment. In the D treatment, the lower development of aminopeptidase together with a better development of $\beta$ glucosidase capacities (higher specific $V_{\mathrm{m}}$, lower $K_{\mathrm{m}}$, and thus a better affinity for substrate) suggested that molecules derived from carbohydrates were used for anabolism and as a source of energy on the one hand and that organic nitrogen sources were more available to heterotrophic bacteria on the other hand, leading to a better global benefit for heterotrophic bacteria as shown by the higher BGE.

The observed differences in ectoenzymatic activities may have been potentially upregulated by trace metals and/or vitamin cofactors or inhibited due to a supply of toxic ele- 
ments. Saharan dust deposition has been suggested as an important source of iron to surface waters (Jickells et al., 2005). There is increasing evidence on the potential role of iron as a cofactor requirement for several enzymes involved in photosynthesis, $\mathrm{N}_{2}$ fixation, and remineralization (Wu et al., 2000; Twining et al., 2004; Browning et al., 2017). In this study, a potential supply of iron or other trace metal elements (i.e., zinc, cobalt) following Saharan dust aerosol addition may have stimulated the bacterial ectoenzymatic activity and/or other metabolic pathways in the D treatment. Conversely, an eventual upload of toxic elements, following anthropogenic aerosols (Paytan et al., 2009; Jordi et al., 2012), may have constrained the bacterial biosynthesis in the A treatment.

A significant amount of dissolved organic nitrogen (DON) was leached from both $\mathrm{A}$ and $\mathrm{D}$ aerosols, highlighting the important contribution of not only $\mathrm{C}$ but also N-containing organic molecules to atmospheric deposition, such as previously reported through atmospheric flux quantification and modeling (Markaki et al., 2010; Djaoudi et al., 2018; Kanakidou et al., 2012, 2018; Galletti et al., 2020). This DON supply resulted in a significant decrease in $\mathrm{C}: \mathrm{N}$ elemental ratios in both the $A$ and $D$ treatments with respect to $\mathrm{G}$, immediately after seeding (Table S2). BGE of natural assemblages of marine bacteria grown on a range of substrates has been shown to be inversely related to the $\mathrm{C}: \mathrm{N}$ ratio of the substrate. Indeed, Goldman al. (1987) showed that the BGE was independent of the source of $\mathrm{C}$ and $\mathrm{N}$ but increased as the $\mathrm{C}: \mathrm{N}$ ratio of the substrate decreased. In this study, although $\mathrm{C}: \mathrm{N}$ stoichiometric ratios were similar in the $\mathrm{D}$ and A aerosol treatments over the incubation period, contrasted BGEs were observed, suggesting that elemental ratios alone were not sufficient to explain the differences between the A and $\mathrm{D}$ treatments, in the conditions of the experiment.

The contrasted BGE and ectoenzymatic development toward access to organic molecules in both the $\mathrm{D}$ and A treatments may have been linked to the primary sources and the chemical composition and/or structure of aerosols as well. Anthropogenic aerosols are associated with various combustion processes, including industrial production, vehicle exhaust, and domestic or waste burning, producing mainly soot particles (Li et al., 2001; Alves et al., 2012; Kanakidou et al., 2012, 2018). These soot particles are generally coated with various organic compounds, forming complex mixtures of highly condensed organic matter. For example, polycyclic aromatic hydrocarbons and a large number of aliphatic compounds are ubiquitous within anthropogenic aerosols (Omar et al., 2006; Alves et al., 2012; Barhoumi et al., 2018). However, these compounds have low water solubility, and thus their contribution to the DOC pool could not alone explain the low BGE observed in the A treatment with respect to both the $D$ and $G$ treatments.

In Mediterranean big cities, the atmospheric organic fraction is also related to secondary organic aerosol (SOA) formation, with a contribution to the fine fraction of aerosols, ranging between $60 \%$ and $80 \%$ (Amato et al., 2016).
In urban atmospheric aerosols, the water-soluble organic carbon has been highlighted as mostly aliphatic in nature (approximately $95 \%$ by $\mathrm{C}$ mass), with major contributions from alkyls and oxygenated alkyls $(\sim 80 \%)$, carboxylic acids $(\sim 10 \%)$, and to a lower extent the aromatic functional group $(\sim 4 \%)$. Among the organic species found in anthropogenic aerosols, alkyls or oxygenated alkyls, (poly)carboxylic acids/carboxylates (e.g., formate and oxalate), sugars (e.g., levoglucosan), and humic-like substances (HULISs) have been reported as the main contributors (Jaffrezo et al., 2005; Sannigrahi et al., 2006; Salma et al., 2013; Theodosi et al., 2018). Recently, HULISs, which are a mixture of high-molecular-weight organic (hydrophobic aliphatic and aromatic) compounds, have been highlighted as contributing a significant proportion of water-soluble organic carbon (up to 70\%) (Zheng et al., 2013; Violotis et al., 2017). Thus, the HULIS compounds' potential contribution to the DOC pool in the A treatment may have constrained the overall bioavailability of energy and carbon and thus the potential of marine bacteria for biosynthesis. Otherwise, an enrichment of anthropogenic aerosols by organic compounds such as formate, acetate, and oxalic and malonic acids has been previously reported in the atmosphere close to emission sources or after atmospheric transport (Sullivan and Prather, 2007; Leaitch et al., 2009; Paris et al., 2010). Some of these compounds (i.e., formate, malonic acids), as being involved in microbial metabolic pathways, could promote respiration and thus a low BGE.

The most abundant organic compounds in dust aerosols revealed a vegetal origin and are more particularly highlighted as the reflection of the past vegetation cover of soils, from which dust aerosols were emitted (Eglinton, 2002). Thus, organic carbon was associated with more or less decomposed biological residues, including microorganism debris, as well as humic substances (Conen et al., 2011). In this study, Saharan dust aerosols were locally sampled within the short timescale of the dust event $(48 \mathrm{~h})$. This may prevent internal mixing of Saharan dust aerosols with other organic compounds in the atmosphere, revealing a higher bioavailable character of the Saharan-dust-derived DOC for marine bacteria, when compared to the anthropogenic-aerosol-derived DOC. Thereby, the higher BGE in the D treatment with respect to A may have been the result of a DOC pool of a vegetal origin, more available to marine bacteria than that derived from anthropogenic emissions. For instance, a probable richness in cellulose-containing molecules in the "fresh" dust used in this study could explain the higher $\beta$ glucosidase activity in the D treatment.

\subsection{Potential implications for the marine carbon cycle in the Mediterranean Sea}

Atmospheric fluxes of DOC in the Mediterranean Sea have been reported to be 6 times higher than river fluxes (Djaoudi et al., 2018; Galletti et al., 2020), highlighting atmospheric 
deposition as a major allochthonous source of carbon to this marine region. Hereafter, we apply the partitioning between labile (LDOC) and refractory DOC (RDOC) in aerosols obtained in this study to these previously reported atmospheric DOC fluxes in the Mediterranean Sea to propose a tentative estimation of LDOC and RDOC fluxes from both Saharan dust and anthropogenic deposition and to which extent they could potentially contribute to the marine carbon cycle.

Although atmospheric deposition is a mixture of different particles from several sources (i.e., anthropogenic, Saharan dust, and/or biomass burning), in order to get a rough estimation of RDOC and LDOC fluxes, we assume that LDOC and RDOC fractions obtained in this study are valid for previous quantifications of atmospheric DOC fluxes (59$120 \mathrm{mmol} \mathrm{m}^{-2} \mathrm{yr}^{-1}$ ) (Djaoudi et al., 2018; Galletti et al., 2020). Note that this assumption would apply to the case of wet deposition events in which an important fraction of atmospheric particles are solubilized in rainwater before deposition. In the case of dry deposition events, the labile and refractory fractions would depend on the potential solubility of atmospheric organic matter in seawater and its residence time in the euphotic layer.

Based on LDOC fractions obtained in this study, atmospheric fluxes of LDOC ranging between 13 and $36 \mathrm{mmol} \mathrm{Cm}^{-2} \mathrm{yr}^{-1}$ and between 11 and $32 \mathrm{mmol} \mathrm{C} \mathrm{m}^{-2} \mathrm{yr}^{-1}$ would be brought from Saharan dust (LDOC: $22 \%-30 \%$ ) and anthropogenic deposition (LDOC: $19 \%-27 \%$ ), respectively.

In the Mediterranean Sea, bacterial carbon demand cannot be satisfied with DOC of autochthonous origin alone (i.e., for instance, phytoplankton DOC extracellular release; Anderson and Turley, 2003) or with terrestrial riverine DOC fluxes (Van Wambeke et al., 1996; Del Giorgio et al., 1997), emphasizing a critical lack in our understanding of sources and sinks of carbon in marine systems. Indeed, using a BGE of $10 \%$, Van Wambeke et al. (2020) examined autochthonous sources of $\mathrm{C}$ through macromolecule hydrolysis and showed that the cumulative hydrolysis rates of $\mathrm{C}$ proteins and $\mathrm{C}$ polysaccharides contributed a small amount to the bacterial carbon demand, on average $2.5 \pm 1.3 \%$ in the epipelagic waters during the spring period. Similarly, measured rates of photosynthetic DOC production represented only $25 \%$ of estimated bacterial carbon demand in the Mediterranean Sea (Marañón et al., 2020). Thus, in such oligotrophic areas, atmospheric deposition of DOC might be one of the missing pieces constraining our understanding of the biogeochemical cycling of carbon, and its labile fraction would be one possible means of contribution to the bacterial carbon demand. To get insight into this potential contribution, atmospheric fluxes of LDOC could be compared to photosynthetic DOC production rates. Such rates are generally obtained during $24 \mathrm{~h}$ long incubations with ${ }^{14} \mathrm{C}$ bicarbonate. It includes not only direct phytoplankton extracellular release but also excretion from grazers and byproducts from viral lysis during the incubations. In the Mediterranean Sea, such fluxes ranged between 4.2 and $10.8 \mathrm{mmol} \mathrm{C} \mathrm{m}^{-2} \mathrm{~d}^{-1}$ (López-Sandoval et al., 2011). By applying the percentages of LDOC observed in this study to previously daily reported atmospheric fluxes (0.03-1.78 $\mathrm{mmol} \mathrm{C} \mathrm{m}^{-2} \mathrm{~d}^{-1}$ ) (Djaoudi et al., 2018; Galletti et al., 2020), atmospheric fluxes of LDOC would range between 0.007 and $0.534 \mathrm{mmol} \mathrm{C} \mathrm{m}^{-2} \mathrm{~d}^{-1}$ for Saharan dust deposition and between 0.006 and $0.480 \mathrm{mmol} \mathrm{C} \mathrm{m}^{-2} \mathrm{~d}^{-1}$ for anthropogenic deposition. These fluxes would thus represent up to $13 \%$ of photosynthetic DOC production, supporting the hypothesis of a potential role of atmospheric deposition of DOC in sustaining secondary production.

The contrasted metabolic pathways evolved by marine heterotrophic bacteria, whether they are facing anthropogenic or Saharan dust aerosols, would potentially influence the fate of derived DOC. When facing anthropogenic aerosols, the result of the present study indicated that most of the consumed carbon is catabolized ( $\mathrm{BGE}=1.7 \%)$ and thus would be returned to the atmosphere as $\mathrm{CO}_{2}$. However, when heterotrophic bacteria are facing Saharan dust aerosols, approximatively $1 / 10$ of the LDOC was incorporated into biomass, resulting in a BGE of $14.2 \pm 5.5 \%$. Nevertheless, atmospheric inputs of labile organic matter can lead to increased remineralization of the marine DOM, potentially acting as a priming effect. Likewise, the marine dissolved organic matter pool, by shaping bacterioplankton composition, could likely influence the microbial utilization of anthropogenic and Saharan-dust-derived organic matter as well, thus influencing BGE. Therefore, investigating the interplay between the different sources of DOM in link with microbial activity would allow further insight regarding the striking interaction between atmospheric deposition and the marine carbon cycle, particularly regarding the role of marine bacteria as a link or sink of carbon.

Aside from a potential contribution of atmospheric DOC deposition in sustaining secondary production, the semilabile and/or refractory fractions of those atmospheric inputs would influence the ocean surface biogeochemistry as well as carbon export. At the timescale of the biodegradation experiment conducted in this study, a large fraction of the initial DOC concentration derived from both Saharan dust (70\%$78 \%)$ and anthropogenic aerosols $(73 \%-81 \%)$ remained non-consumed, suggesting a significant input of semi-labile and/or refractory DOC into seawater from aerosol dissolution. DOC export has been highlighted as playing a critical role within the biological carbon pump in the Mediterranean Sea, leading to an export of $17 \mathrm{~g} \mathrm{C} \mathrm{m}^{-2} \mathrm{yr}^{-1}$ (Guyennon et al., 2015). Estimated as for LDOC, RDOC fluxes would range between 0.5 and $1.1 \mathrm{~g} \mathrm{C} \mathrm{m}^{-2} \mathrm{yr}^{-1}$ for Saharan dust deposition and between 0.5 and $1.2 \mathrm{~g} \mathrm{C} \mathrm{m}^{-2} \mathrm{yr}^{-1}$ for anthropogenic deposition. Thereby, the contribution of refractory DOC derived from Saharan dust and anthropogenic deposition would contribute to the DOC export of $3 \%-6.5 \%$ and $3 \%-7 \%$, respectively, likely influencing the biological carbon pump, especially in increasing scenarios of atmospheric emissions. 


\section{Conclusion}

Organic carbon derived from anthropogenic aerosols exhibited a higher solubility (32\%) with respect to Saharan dust $(13 \%)$. Despite such a difference, the amount of bioavailable dissolved organic carbon (DOC) to marine heterotrophic bacteria was quantitatively similar, with contributions of the labile dissolved organic carbon to the total dissolved organic fraction of $25 \pm 4 \%$ and $24 \%$ in Saharan dust and anthropogenic aerosols, respectively. Interestingly, the bacterial growth efficiency (BGE) in the Saharan dust treatment $(14.2 \pm 5.5 \%)$ was higher than that of the anthropogenic treatment $(1.7 \%)$, suggesting differences in the metabolic response depending on the aerosol source. This study reveals a new link between atmospheric deposition and the oceanic carbon cycle. Indeed, inputs of atmospheric anthropogenic carbon to the ocean could promote its respiration by bacterial communities. In contrast, carbon derived from Saharan dust aerosols may contribute to biomass production. These results question the future trajectory of ocean-climate feedbacks in oligotrophic oceans, particularly in increasing scenarios of anthropogenic emissions.

Data availability. Data used in this study are available from the corresponding author Kahina Djaoudi upon request at kdjaoudi@email.arizona.edu.

Supplement. The supplement related to this article is available online at: https://doi.org/10.5194/bg-17-6271-2020-supplement.

Author contributions. KDj and EPV conceived the study and the sampling design. KDj wrote the manuscript. NB collected seawater for the inoculum preparation. AN collected anthropogenic aerosols. MT, THdT, ML collected Saharan dust aerosols. KDe, SC analyzed atmospheric aerosols. KDj, EPV, FVW, AN, DL subsampled the mesocosms. KDj, FVW, AB, SN, CP analyzed the samples. $\mathrm{KDj}$, EPV, FV analyzed the data, and all authors assisted with data discussion and contributed to the revision and editing of the final manuscript. All authors are aware of and accept responsibility for this paper and have approved the final submitted manuscript.

Competing interests. The authors declare that they have no conflict of interest.

Special issue statement. This article is part of the special issue "Atmospheric deposition in the low-nutrient-low-chlorophyll (LNLC) ocean: effects on marine life today and in the future (ACP/BG interjournal SI)". It is not associated with a conference.

Acknowledgements. This study was conducted as part of the WP4 Mermex/Mistral project and is a contribution to the PEACETIME research project and to the international SOLAS program. This work received the support from the Institut des Régions Arides (IRA) from Médenine, Tunisia, as well as the IRD French-Tunisian International Joint Laboratory (LMI) "COSYSMed". The authors would like to thank the PRECYM Cytometry platform. The authors also acknowledge Jean-Louis Rajot for his constructive comments. We are grateful to Mariana Bernadi Bif and the one anonymous reviewer for their helpful suggestions during the peer review process. The associated editor, Cécile Guieu, is acknowledged for her relevant comments and suggestions on the paper.

Financial support. This work is a contribution to the Labex OTMed (no. ANR-11-LABX-0061) funded by the French government "Investissements d'Avenir" program of the French National Research Agency (ANR) through the A*MIDEX project (no. ANR11-IDEX-0001-02). Kahina Djaoudi was supported by the Labex OTMed through a $\mathrm{PhD}$ grant. This research was funded by the French national LEFE-CYBER program through the project BATO (Dissolution and bioavailability of aerosols-derived terrestrial organic matter at the ocean-atmosphere interface).

Review statement. This paper was edited by Cecile Guieu and reviewed by Mariana Bernardi Bif and one anonymous referee.

\section{References}

Anderson, T. R. and Turley, C. M.: Low bacterial growth efficiency in the oligotrophic eastern Mediterranean Sea: a modelling analysis, J. Plankton Res., 25, 1011-1019, https://doi.org/10.1093/plankt/25.9.1011, 2003.

Alves, C., Vicente, A., Pio, C., Kiss, G., Hoffer, A., Decesari, S., Prevôt, A. S., Minguillón, M. C., Querol, X., and Hillamo, R.: Organic compounds in aerosols from selected European sites - Biogenic versus anthropogenic sources, Atmos. Environ., 59, 243-255, 2012.

Amato, F., Alastuey, A., Karanasiou, A., Lucarelli, F., Nava, S., Calzolai, G., Severi, M., Becagli, S., Gianelle, V. L., Colombi, C., Alves, C., Custódio, D., Nunes, T., Cerqueira, M., Pio, C., Eleftheriadis, K., Diapouli, E., Reche, C., Minguillón, M. C., Manousakas, M.-I., Maggos, T., Vratolis, S., Harrison, R. M., and Querol, X.: AIRUSE-LIFE+: a harmonized PM speciation and source apportionment in five southern European cities, Atmos. Chem. Phys., 16, 3289-3309, https://doi.org/10.5194/acp16-3289-2016, 2016.

Ammermann, J. W., Furhman, J. A., Hagström, A., and Azam, F.: Bacterioplankton growth in sea water: I. Growth kinetics and cellular characteristics in sea water cultures, Mar. Ecol.-Prog. Ser., 18, 31-39, 1984.

Aminot, A. and Kerouel., R.: Dosage automatique des nutriments dans les eaux marines. Méthodes en flux continu, MEDD Editions Quae, Brest, 188 pp., 2007.

Azam, F.: Microbial Control of Oceanic Carbon Flux: The Plot Thickens, Science, 280, 694-696, https://doi.org/10.1126/science.280.5364.694, 1998 
Azam, F., Fenchel, T., Field, J. G., Gray, J., Meyer-Reil, L., and Thingstad, F.: The ecological role of water-column microbes in the sea, Mar. Ecol.-Prog. Ser., 10, 257-263, 1983.

Barhoumi, B., Castro-Jiménez, J., Guigue, C., Goutx, M., Sempéré, R., Derouiche, A., Achour, A., Touil, S., Driss, M. R., and Tedetti, M.: Levels and risk assessment of hydrocarbons and organochlorines in aerosols from a North African coastal city (Bizerte, Tunisia), Environ. Pollut., 240, 422-431, 2018.

Biddanda, B., Opsahl, S., and Benner, R.: Plankton respiration and carbon flux through bacterioplankton on the Louisiana shelf, Limnol. Oceanogr., 39, 1259-1275, 1994.

Browning, T. J., Achterberg, E. P., Yong, J. C., Rapp, I., Utermann, C., Engel, A., and Moore, C. M.: Iron limitation of microbial phosphorus acquisition in the tropical North Atlantic, Nat. Commun., 8, 15465, https://doi.org/10.1038/ncomms15465, 2017.

Bif, M. B., Hansell, D. A., and Popendorf, K. J.: Controls on the fate of dissolved organic carbon under contrasting upwelling conditions, Front. Mar. Sci., 5, 463, https://doi.org/10.3389/Fmars.2018.00463, 2018.

Bunse, C. and Pinhassi, J.: Marine bacterioplankton seasonal succession dynamics, Trends Microbiol., 25, 494-505, 2017.

Carlson, A.: Production and Removal Processes, in: Biogeochemistry of dissolved organic matter, 1st Edn., Hansell, D. and Carlson, A., Academic Press, London, 91-151, 2002.

Carlson, C. A. and Ducklow, H. W.: Growth of bacterioplankton and consumption of dissolved organic carbon in the Sargasso Sea, Aquat. Microb. Ecol., 10, 69-85, 1996.

Carlson, C. A., Ducklow, H. W., and Michaels, A. F.: annual flux of dissolved organic-carbon from the euphotic zone in the northwestern Sargasso Sea, Nature, 371, 405-408, https://doi.org/10.1038/371405a0, 1994.

Cavalli, F., Viana, M., Yttri, K. E., Genberg, J., and Putaud, J.-P.: Toward a standardised thermal-optical protocol for measuring atmospheric organic and elemental carbon: the EUSAAR protocol, Atmos. Meas. Tech., 3, 79-89, https://doi.org/10.5194/amt-3-792010, 2010.

Conen, F., Morris, C. E., Leifeld, J., Yakutin, M. V., and Alewell, C.: Biological residues define the ice nucleation properties of soil dust, Atmos. Chem. Phys., 11, 9643-9648, https://doi.org/10.5194/acp-11-9643-2011, 2011.

Dall'Osto, M., Harrison, R. M., Highwood, E. J., O’Dowd, C., Ceburnis, D., Querol, X., and Achterberg, E. P.: Variation of the mixing state of Saharan dust particles with atmospheric transport, Atmos. Environ., 44, 3135-3146, 2010.

De Leeuw, G., Guieu, C., Arneth, A., Bellouin, N., Bopp, L., Boyd, P. W., van der Gon, H. A. D., Desboeufs, K. V., Dulac, F., and Facchini, M. C.: Ocean-atmosphere interactions of particles, in: Ocean-Atmosphere Interactions of Gases and Particles, Springer, Berlin, 171-246, 2014.

del Giorgio, P. A. and Cole, J. J.: Bacterial growth efficiency in natural aquatic systems, Annu. Rev. Ecol. Syst., 29, 503-541, https://doi.org/10.1146/annurev.ecolsys.29.1.503, 1998.

del Giorgio, P. A., Cole, J. J., and Cimbleris, A.: Respiration rates in bacteria exceed phytoplankton production in unproductive aquatic systems, Nature, 385, 148-151, 1997.

Djaoudi, K., Van Wambeke, F., Barani, A., Hélias-Nunige, S., Sempere, R., and Pulido-Villena, E.: Atmospheric fluxes of soluble organic C, N, and P to the Mediterranean Sea: Potential biogeo- chemical implications in the surface layer, Prog. Oceanogr., 163, 59-69, 2018

Duce, R. A., Liss, P. S., Merrill, J. T., Atlas, E. L., Buat-Menard, P., Hicks, B. B., Miller, J. M., Prospero, J. M., Arimoto, R., Church, T. M., Ellis, W., Galloway, J. N., Hansen, L., Jickells, T. D., Knap, A. H., Reinhardt, K. H., Schneider, B., Soudine, A., Tokos, J. J., Tsunogai, S., Wollast, R., and Zhou, M.: The atmospheric input of trace species to the world ocean, Global Biogeochem. Cy., 5, 193-259, https://doi.org/10.1029/91GB01778, 1991.

Duce, R. A., LaRoche, J., Altieri, K., Arrigo, K. R., Baker, A. R., Capone, D. G., Cornell, S., Dentener, F., Galloway, J., Ganeshram, R. S., Geider, R. J., Jickells, T., Kuypers, M. M., Langlois, R., Liss, P. S., Liu, S. M., Middelburg, J. J., Moore, C. M., Nickovic, S., Oschlies, A., Pedersen, T., Prospero, J., Schlitzer, R., Seitzinger, S., Sorensen, L. L., Uematsu, M., Ulloa, O., Voss, M., Ward, B., and Zamora, L.: Impacts of atmospheric anthropogenic nitrogen on the open ocean, Science, 320, 893-897, https://doi.org/10.1126/science.1150369, 2008.

Eglinton, T. I., Eglinton, G., Dupont, L., Sholkovitz, E., Montluçon, D., and Reddy, C.: Composition, age, and provenance of organic matter in NW African dust over the Atlantic Ocean, Geochem. Geophy. Geosy., 3, 1-27, 2002.

Falkovich, A. H., Schkolnik, G., Ganor, E., and Rudich, Y.: Adsorption of organic compounds pertinent to urban environments onto mineral dust particles, J. Geophys. Res.-Atmos., 109, D02208, https://doi.org/10.1029/2003jd003919, 2004.

Fenchel, T. and Blackburn, T. H.: Bacteria and mineral cycling, Academic Press, Inc. (London) Ltd., 1979.

Fuhrman, J.: Bacterioplankton Roles in Cycling of Organic Matter: The Microbial Food Web, in: Primary Productivity and Biogeochemical Cycles in the Sea, edited by: Falkowski, P. G., Woodhead, A. D., and Vivirito, K., Environmental Science Research, Vol. 43, Springer, Boston, MA, https://doi.org/10.1007/978-14899-0762-2_20, 1992.

Galletti, Y., Becagli, S., di Sarra, A., Gonnelli, M., Pulido-Villena, E., Sferlazzo, D. M., Traversi, R., Vestri, S., and Santinelli, C.: Atmospheric deposition of organic matter at a remote site in the central Mediterranean Sea: implications for the marine ecosystem, Biogeosciences, 17, 3669-3684, https://doi.org/10.5194/bg17-3669-2020, 2020.

Gasol, J. M. and Kirchman, D. L.: The evolution of microbial ecology of the ocean, in: Microbial ecology of the oceans, edited by: Gasol, J. M., Kirchman, D. L., 4rd Edn., John Wiley \& Sons, Hoboken, NJ, USA, 528 pp., 2018.

Goldman, J. C., Caron, D. A., and Dennett, M. R.: Regulation of gross growth efficiency and ammonium regeneration in bacteria by substrate $\mathrm{C}: \mathrm{N}$ ratio 1 , Limnol. Oceanogr., 32, 1239-1252, 1987.

Guieu, C., Aumont, O., Paytan, A., Bopp, L., Law, C. S., Mahowald, N., Achterberg, E. P., Maranon, E., Salihoglu, B., Crise, A., Wagener, T., Herut, B., Desboeufs, K., Kanakidou, M., Olgun, N., Peters, F., Pulido-Villena, E., Tovar-Sanchez, A., and Volker, C.: The significance of the episodic nature of atmospheric deposition to Low Nutrient Low Chlorophyll regions, Global Biogeochem. Cy., 28, 1179-1198, https://doi.org/10.1002/2014gb004852, 2014.

Guyennon, A., Baklouti, M., Diaz, F., Palmieri, J., Beuvier, J., Lebaupin-Brossier, C., Arsouze, T., Béranger, K., Dutay, J.-C., and Moutin, T.: New insights into the organic carbon export in 
the Mediterranean Sea from 3-D modeling, Biogeosciences, 12, 7025-7046, https://doi.org/10.5194/bg-12-7025-2015, 2015.

Hansell, D. A.: Dissolved organic carbon reference material program, EOS T. Am. Geophys. Un., 86, 318-318, 2005.

Hansell, D. A., Carlson, C. A., Repeta, D. J., and Schlitzer, R.: Dissolved organic matter in the ocean a controversy stimulates new insights, Oceanography, 22, 202-211, 2009.

Herut, B., Rahav, E., Tsagaraki, T. M., Giannakourou, A., Tsiola, A., Psarra, S., Lagaria, A., Papageorgiou, N., Mihalopoulos, N., Theodosi, C. N., Violaki, K., Stathopoulou, E., Scoullos, M., Krom, M. D., Stockdale, A., Shi, Z., Berman-Frank, I., Meador, T. B., Tanaka, T., and Paraskevi, P.: The Potential Impact of Saharan Dust and Polluted Aerosols on Microbial Populations in the East Mediterranean Sea, an Overview of a Mesocosm Experimental Approach, Front. Mar. Sci., 3, 226, https://doi.org/10.3389/fmars.2016.00226, 2016.

Hoppe, H.-G.: Significance of exoenzymatic activities in the ecology of brackish water: measurements by means of methylumbelliferyl-substrates, Mar. Ecol.-Prog. Ser., 11, 299308,1983 .

Jaffrezo, J.-L., Aymoz, G., Delaval, C., and Cozic, J.: Seasonal variations of the water soluble organic carbon mass fraction of aerosol in two valleys of the French Alps, Atmos. Chem. Phys., 5, 2809-2821, https://doi.org/10.5194/acp-5-2809-2005, 2005.

Jiao, N., Herndl, G. J., Hansell, D. A., Benner, R., Kattner, G., Wilhelm, S. W., Kirchman, D. L., Weinbauer, M. G., Luo, T. W., Chen, F., and Azam, F.: Microbial production of recalcitrant dissolved organic matter: long-term carbon storage in the global ocean, Nat. Rev. Microbiol., 8, 593-599, https://doi.org/10.1038/nrmicro2386, 2010.

Jickells, T. D., An, Z. S., Andersen, K. K., Baker, A. R., Bergametti, G., Brooks, N., Cao, J. J., Boyd, P. W., Duce, R. A., Hunter, K. A., Kawahata, H., Kubilay, N., laRoche, J., Liss, P. S., Mahowald, N., Prospero, J. M., Ridgwell, A. J., Tegen, I., and Torres, R.: Global Iron Connections Between Desert Dust, Ocean Biogeochemistry, and Climate, Science, 308, 6771, https://doi.org/10.1126/science.1105959, 2005.

Jordi, A., Basterretxea, G., Tovar-Sanchez, A., Alastuey, A., and Querol, X.: Copper aerosols inhibit phytoplankton growth in the Mediterranean Sea, P. Natl. Acad. Sci. USA, 109, 21246-21249, https://doi.org/10.1073/pnas.1207567110, 2012.

Kanakidou, M., Duce, R. A., Prospero, J. M., Baker, A. R., BenitezNelson, C., Dentener, F. J., Hunter, K. A., Liss, P. S., Mahowald, N., Okin, G. S., Sarin, M., Tsigaridis, K., Uematsu, M., Zamora, L. M., and Zhu, T.: Atmospheric fluxes of organic N and $\mathrm{P}$ to the global ocean, Global Biogeochem. Cy., 26, GB3026, https://doi.org/10.1029/2011gb004277, 2012.

Kanakidou, M., Myriokefalitakis, S., and Tsigaridis, K.: Aerosols in atmospheric chemistry and biogeochemical cycles of nutrients, Environ. Res. Lett., 13, 063004, https://doi.org/10.1088/17489326/Aabcdb, 2018.

Kirchman, D. L.: Processes in Microbial Ecology, 2nd Edn., Vol. 1, Oxford University Press, Oxford, UK, https://doi.org/10.1093/oso/9780198789406.001.0001, 2018.

Kirchman, D. L., Ducklow, H. W., and Mitchell, R.: Estimates of bacterial growth from changes in uptake rates and biomass, Appl. Environ. Microb., 44, 1296-1307, 1982.

Kirchman, D. L., Keil, R. G., Simon, M., and Welschmeyer, N. A.: Biomass and production of heterotrophic bacterioplancton in the oceanic Sub-Arctic Pacific, Deep-Sea Res. Pt. I, 40, 967-988, https://doi.org/10.1016/0967-0637(93)90084-g, 1993.

Leaitch, W. R., Macdonald, A. M., Anlauf, K. G., Liu, P. S. K., Toom-Sauntry, D., Li, S.-M., Liggio, J., Hayden, K., Wasey, M. A., Russell, L. M., Takahama, S., Liu, S., van Donkelaar, A., Duck, T., Martin, R. V., Zhang, Q., Sun, Y., McKendry, I., Shantz, N. C., and Cubison, M.: Evidence for Asian dust effects from aerosol plume measurements during INTEXB 2006 near Whistler, BC, Atmos. Chem. Phys., 9, 3523-3546, https://doi.org/10.5194/acp-9-3523-2009, 2009.

Lechtenfeld, O. J., Hertkorn, N., Shen, Y., Witt, M., and Benner, R.: Marine sequestration of carbon in bacterial metabolites, Nat Commun., 6, 6711, https://doi.org/10.1038/ncomms7711, 2015.

Letelier, R. M., Björkman, K. M., Church, M. J., Hamilton, D. S., Mahowald, N. M., Scanza, R. A., Schneider, N., White, A. E., and Karl, D. M.: Climate-driven oscillation of phosphorus and iron limitation in the North Pacific Subtropical Gyre, P. Natl. Acad. Sci. USA, 116, 12720-12728, 2019.

Letscher, R. T. and Moore, J. K.: Preferential remineralization of dissolved organic phosphorus and non-Redfield DOM dynamics in the global ocean: Impacts on marine productivity, nitrogen fixation, and carbon export, Global Biogeochem. Cy., 29, 325-340, https://doi.org/10.1002/2014gb004904, 2015.

Li, C.-T., Zhuang, H.-K., Hsieh, L.-T., Lee, W.-J., and Tsao, M.C.: PAH emission from the incineration of three plastic wastes, Environ. Int., 27, 61-67, 2001.

Lønborg, C. and Álvarez-Salgado, X. A.: Recycling versus export of bioavailable dissolved organic matter in the coastal ocean and efficiency of the continental shelf pump, Global Biogeochem. Cy., 26, GB3018, https://doi.org/10.1029/2012GB004353, 2012.

López-Sandoval, D. C., Fernández, A., and Marañón, E.: Dissolved and particulate primary production along a longitudinal gradient in the Mediterranean Sea, Biogeosciences, 8, 815-825, https://doi.org/10.5194/bg-8-815-2011, 2011.

Marañón, E., Fernández, A., Mouriño-Carballido, B., MartínezGarcÍa, S., Teira, E., Cermeño, P., Chouciño, P., Huete-Ortega, M., Fernández, E., Calvo-DÍaz, A., Morán, X. A. G., Bode, A., Moreno-Ostos, E., Varela, M. M., Patey, M. D., and Achterberg, E. P.: Degree of oligotrophy controls the response of microbial plankton to Saharan dust, Limnol. Oceanogr., 55, 2339-2352, https://doi.org/10.4319/lo.2010.55.6.2339, 2010.

Marañón, E., Van Wambeke, F., Uitz, J., Boss, E. S., Pérez-Lorenzo, M., Dinasquet, J., Haëntjens, N., Dimier, C., and Taillandier, V.: Deep maxima of phytoplankton biomass, primary production and bacterial production in the Mediterranean Sea during late spring, Biogeosciences Discuss., https://doi.org/10.5194/bg2020-261, in review, 2020.

Marie, D., Simon, N., Guillou, L., Partensky, F., and Vaulot, D.: DNA/RNA analysis of phytoplankton by flow cytometry, in: Current protocols in cytometry, edited by: Robinson, J. P., Darzynkiewicz, Z., Dean, P. N., Dressler, L. G., Rabinovitch, P. S., Stewart, C. C., Tanke, H. J., Wheeless, L. L., John Wiley \& Sons, New York, 11-12, https://doi.org/10.1002/0471142956.cy1112s11, 2002.

Marín, I., Nunes, S., Sánchez-Pérez, E. D., Txurruka, E., Antequera, C., Sala, M. M., Marrasé, C., and Peters, F.: Coastal bacterioplankton metabolism is stimulated stronger by anthropogenic aerosols than saharan dust, Front. Mmicrobiol., 8, 2215, https://doi.org/10.3389/fmicb.2017.02215, 2017a. 
Marín, I., Nunes, S., Sánchez-Pérez, E. D., Aparicio, F., Estrada, M., Marrasé, C., Moreno, T., Wagener, T., Querol, X., and Peters, F.: Anthropogenic versus mineral aerosols in the stimulation of microbial planktonic communities in coastal waters of the northwestern Mediterranean Sea, Sci. Total Environ., 574, 553-568, $2017 b$.

Markaki, Z., Loye-Pilot, M. D., Violaki, K., Benyahya, L., and Mihalopoulos, N.: Variability of atmospheric deposition of dissolved nitrogen and phosphorus in the Mediterranean and possible link to the anomalous seawater N/P ratio, Mar. Chem., 120, 187-194, https://doi.org/10.1016/j.marchem.2008.10.005, 2010.

Moran, M. A., Kujawinski, E. B., Stubbins, A., Fatland, R., Aluwihare, L. I., Buchan, A., Crump, B. C., Dorrestein, P. C., Dyhrman, S. T., and Hess, N. J.: Deciphering ocean carbon in a changing world, P. Natl. Acad. Sci. USA, 113, 3143-3151, 2016.

Omar, N. Y. M., Mon, T. C., Rahman, N. A., and Abas, M. R. B.: Distributions and health risks of polycyclic aromatic hydrocarbons (PAHs) in atmospheric aerosols of Kuala Lumpur, Malaysia, Sci. Total Environ., 369, 76-81, 2006.

Paris, R., Desboeufs, K. V., Formenti, P., Nava, S., and Chou, C.: Chemical characterisation of iron in dust and biomass burning aerosols during AMMA-SOP0/DABEX: implication for iron solubility, Atmos. Chem. Phys., 10, 4273-4282, https://doi.org/10.5194/acp-10-4273-2010, 2010.

Paytan, A., Mackey, K. R. M., Chen, Y., Lima, I. D., Doney, S. C., Mahowald, N., Labiosa, R., and Postf, A. F.: Toxicity of atmospheric aerosols on marine phytoplankton, Proc. Natl. Acad. Sci. USA, 106, 4601-4605, https://doi.org/10.1073/pnas.0811486106, 2009.

Prospero, J. M., Bullard, J. E., and Hodgkins, R.: HighLatitude Dust Over the North Atlantic: Inputs from Icelandic Proglacial Dust Storms, Science, 335, 1078-1082, https://doi.org/10.1126/science.1217447, 2012.

Pujo-Pay, M. and Raimbault, P.: Improvement of the wet-oxidation procedure for simultaneous determination of particulate organic nitrogen and phosphorus collected on filters, Mar. Ecol.-Prog. Ser., 105, 203-203, 1994.

Pulido-Villena, E., Wagener, T., and Guieu, C.: Bacterial response to dust pulses in the western Mediterranean: Implications for carbon cycling in the oligotrophic ocean, Global Biogeochem. Cy., 22, 1-5, https://doi.org/10.1029/2007GB003091, 2008.

Pulido-Villena, E., Rerolle, V., and Guieu, C.: Transient fertilizing effect of dust in P-deficient LNLC surface ocean, Geophys. Res. Lett., 37, 1-5, https://doi.org/10.1029/2009g1041415, 2010.

Romera-Castillo, C., Letscher, R. T., and Hansell, D. A.: New nutrients exert fundamental control on dissolved organic carbon accumulation in the surface Atlantic Ocean, P. Natl. Acad. Sci. USA, 113, 10497-10502, 2016.

Roshan, S. and DeVries, T.: Efficient dissolved organic carbon production and export in the oligotrophic ocean, Nat. Commun., 8, $1-8,2017$.

Salma, I., Mészáros, T., and Maenhaut, W.: Mass size distribution of carbon in atmospheric humic-like substances and water-soluble organic carbon for an urban environment, J. Aerosol Sci., 56, 5360, 2013.

Sannigrahi, P., Sullivan, A. P., Weber, R. J., and Ingall, E. D.: Characterization of water-soluble organic carbon in urban atmospheric aerosols using solid-state ${ }^{13} \mathrm{C}$ NMR spectroscopy, Environ. Sci. Technol., 40, 666-672, 2006.
Sipler, R. E. and Bronk, D. A.: Dynamics of dissolved organic nitrogen, in: Biogeochemistry of marine dissolved organic matter, edited by: Hansell, D. and Carlson, A., 2nd Edn., Elsevier, London, 127-232, 2015.

Smith, D. C. and Azam, F.: A simple, economical method for measuring bacterial protein synthesis rates in seawater using ${ }^{3} \mathrm{H}$ leucine, Mar. Microb. Food Webs, 6, 107-114, 1992.

Sullivan, R. C. and Prather, K. A.: Investigations of the diurnal cycle and mixing state of oxalic acid in individual particles in Asian aerosol outflow, Environ. Sci. Technol., 41, 8062-8069, 2007.

Theodosi, C., Panagiotopoulos, C., Nouara, A., Zarmpas, P., Nicolaou, P., Violaki, K., Kanakidou, M., Sempéré, R., and Mihalopoulos, N.: Sugars in atmospheric aerosols over the Eastern Mediterranean, Prog. Oceanogr., 163, 70-81, https://doi.org/10.1016/j.pocean.2017.09.001, 2018.

Tsagaraki, T. M., Herut, B., Rahav, E., Frank, I. R. B., Tsiola, A., Tsapakis, M., Giannakourou, A., Gogou, A., Panagiotopoulos, C., Violaki, K., Psarra, S., Lagaria, A., Christou, E. D., Papageorgiou, N., Zervoudaki, S., de Puelles, M. L. F., Nikolioudakis, N., Meador, T. B., Tanaka, T., Pedrotti, M. L., Krom, M. D., and Pitta, P.: Atmospheric Deposition Effects on Plankton Communities in the Eastern Mediterranean: A Mesocosm Experimental Approach, Front. Mar. Sci., 4, 210, https://doi.org/10.3389/Fmars.2017.00210, 2017.

Twining, B. S., Baines, S. B., and Fisher, N. S.: Element stoichiometries of individual plankton cells collected during the Southern Ocean Iron Experiment (SOFeX), Limnol. Oceanogr., 49, 21152128, 2004.

Van Wambeke, F., Christaki, U., and Gaudy, R.: Carbon fluxes from the microbial food web to mesozooplankton. An approach in the surface layer of a pelagic area (NW Mediterranean Sea), Oceanol. Acta, 19, 57-66, 1996.

Van Wambeke, F., Pulido, E., Dinasquet, J., Djaoudi, K., Engel, A., Garel, M., Guasco, S., Nunige, S., Taillandier, V., Zäncker, B., and Tamburini, C.: Spatial patterns of biphasic ectoenzymatic kinetics related to biogeochemical properties in the Mediterranean Sea, Biogeosciences Discuss., https://doi.org/10.5194/bg-2020253, in review, 2020.

Vila-Costa, M., Sebastián, M., Pizarro, M., Cerro-Gálvez, E., Lundin, D., Gasol, J. M., and Dachs, J.: Microbial consumption of organophosphate esters in seawater under phosphorus limited conditions, Sci. Rep.-UK, 9, 1-11, 2019.

Violaki, K., Bourrin, F., Aubert, D., Kouvarakis, G., Delsaut, N., and Mihalopoulos, N.: Organic Phosphorus in atmospheric deposition over Mediterranean Sea: An important missing piece of the P cycle, Prog. Oceanogr., 163, 50-58, 2018.

Voliotis, A., Prokeš, R., Lammel, G., and Samara, C.: New insights on humic-like substances associated with wintertime urban aerosols from central and southern Europe: size-resolved chemical characterization and optical properties, Atmos. Enviro., 166, 286-299, 2017.

Wu, J. F., Sunda, W., Boyle, E. A., and Karl, D. M.: Phosphate depletion in the western North Atlantic Ocean, Science, 289, 759762, https://doi.org/10.1126/science.289.5480.759, 2000.

Zheng, G., He, K., Duan, F., Cheng, Y., and Ma, Y.: Measurement of humic-like substances in aerosols: A review, Environ. Pollut., 181, 301-314, 2013. 